\title{
Circular RNA detection identifies circPSEN1 alterations in brain specific to Autosomal Dominant Alzheimer Disease
}

Hsiang-Han Chen ${ }^{1,2}$, Abdallah Eteleeb ${ }^{1,2}$, Ciyang Wang ${ }^{1,2}$, Maria Victoria Fernandez $^{1,2}$, John P. Budde ${ }^{1,2}$, Kristy Bergmann ${ }^{1,2}$, Joanne Norton ${ }^{1,2}$, Fengxian Wang ${ }^{1,2}$, Curtis Ebl $^{1,2}$, John C. Morris ${ }^{3,4,5}$, Richard J. Perrin $^{3,4,5,6}$, Randall J. Bateman ${ }^{3,4,5}$, Eric McDade ${ }^{5}$, Chengjie Xiong ${ }^{7}$, Alison Goate ${ }^{8}$, Martin Farlow ${ }^{9}$, Jasmeer Chhatwal ${ }^{10}$, Peter R Schofield ${ }^{11,12}$, Helena Chui ${ }^{13}$, Oscar Harari ${ }^{1,2,3,4}$, Carlos Cruchaga ${ }^{1,2,3,4,5,14}$, Laura Ibanez ${ }^{1,2}$, Dominantly Inherited Alzheimer Network

1- Department of Psychiatry, Washington University in Saint Louis School of Medicine

2- NeuroGenomics and Informatics Center, Washington University in Saint Louis School of Medicine

3- Hope Center for Neurological Disorders, Washington University in Saint Louis School of Medicine

4- The Charles F. and Joanne Knight Alzheimer Disease Research Center, Washington University in Saint Louis School of Medicine

5- Department of Neurology, Washington University in Saint Louis School of Medicine

6- Department of Pathology and Immunology, Washington University in Saint Louis School of Medicine

7- Division of Biostatistics, Washington University in Saint Louis School of Medicine

8- Neuroscience, Icahn School of Medicine at Mount Sinai

9- Department of Neurology, Indiana University School of Medicine

10- Department of Neurology, Massachusetts General Hospital

11- Neuroscience Research Australia, Sydney, Australia

12- School of Medical Sciences, University of New South Wales, Sydney, Australia

13- Department of Neurology, Keck School of Medicine of University of Southern California

14- Department of Genetics, Washington University in Saint Louis School of Medicine

Word Count: 4,067

Tables: 3

Figures: 2 
medRxiv preprint doi: https://doi.org/10.1101/2021.10.29.21265617; this version posted October 30, 2021. The copyright holder for this preprint (which was not certified by peer review) is the author/funder, who has granted medRxiv a license to display the preprint in perpetuity.

It is made available under a CC-BY-NC-ND 4.0 International license .

\section{Abstract}

Background: Autosomal-dominant Alzheimer's disease (ADAD) is caused by pathogenic mutations in APP, PSEN1, and PSEN2, which usually lead to an early age at onset $(<65)$. Circular RNAs are a family of noncoding RNAs highly expressed in the nervous system and especially in synapses. We aimed to investigate differences in brain gene expression of linear and circular transcripts from the three ADAD genes in controls, sporadic AD, and ADAD.

Methods: We obtained and sequenced RNA from brain cortex using standard protocols. Linear counts were obtained using the TOPMed pipeline; circular counts, using python package DCC. After stringent quality control (QC), we obtained the counts for PSEN1, PSEN2 and APP genes. Only circPSEN1 passed QC. We used DESeq2 to compare the counts across groups, correcting for biological and technical variables. Finally, we performed in-silico functional analyses using the Circular RNA interactome website and DIANA mirPath software.

Results: Our results show significant differences in gene counts of circPSEN1 in ADAD individuals, when compared to sporadic $A D$ and controls $(A D A D=22, A D=274$, Controls $=25-A D A D v s C O: \log 2 F C=0.786$, $p=9.08 \times 10-05$, ADADvsAD: $\log 2 F C=0.576, p=2.00 \times 10-03)$. The high gene counts are contributed by two circPSEN1 species (hsa_circ_0008521 and hsa_circ_0003848). No significant differences were observed in linear PSEN1 gene expression between cases and controls, indicating that this finding is specific to the circular forms. In addition, the high circPSEN1 levels do not seem to be specific to PSEN1 mutation carriers; the counts are also elevated in APP and PSEN2 mutation carriers. In-silico functional analyses suggest that cirCPSEN1 is involved in several pathways such as axon guidance $\left(p=3.39 \times 10^{-07}\right)$, hippo signaling pathway $\left(p=7.38 \times 10^{-07}\right)$, lysine degradation $\left(p=2.48 \times 10^{-05}\right)$ or Wnt signaling pathway $\left(p=5.58 \times 10^{-04}\right)$ among other KEGG pathways. Additionally, circPSEN1 counts were able to discriminate ADAD from sporadic AD and controls with an AUC above 0.70 . 
medRxiv preprint doi: https://doi.org/10.1101/2021.10.29.21265617; this version posted October 30, 2021. The copyright holder for this preprint (which was not certified by peer review) is the author/funder, who has granted medRxiv a license to display the preprint in perpetuity. It is made available under a CC-BY-NC-ND 4.0 International license.

Conclusions: Our findings show the differential expression of circPSEN1 is increased in ADAD. Given the biological function previously ascribed to circular RNAs and the results of our in-silico analyses, we hypothesize that this finding might be related to neuroinflammatory events that lead or that are caused by the accumulation of amyloid-beta. 
medRxiv preprint doi: https://doi.org/10.1101/2021.10.29.21265617; this version posted October 30, 2021. The copyright holder for this preprint (which was not certified by peer review) is the author/funder, who has granted medRxiv a license to display the preprint in perpetuity.

It is made available under a CC-BY-NC-ND 4.0 International license .

\section{1.- Background}

Alzheimer disease (AD) is the most common cause of dementia; approximately 5.8 million Americans suffered from AD in 2019 and, by 2050, it is projected that 14 million individuals in the United States will be affected by $A D[1]$. AD is characterized by pathological changes in the brain: accumulation of amyloidbeta plaques (extracellular deposits of amyloid-beta peptides) and neurofibrillary tangles (NFTs, intraneuronal fibrillar aggregates of hyperphosphorylated tau). Clinically, AD is defined by gradual and progressive memory loss [2]. AD can be categorized as sporadic AD or Autosomal Dominant AD (ADAD) [3]. ADAD is caused by mutations or duplications of the amyloid precursor protein (APP), mutations in presenilin 1 (PSEN1), or mutations in presenilin 2 (PSEN2), an autosomal dominant inheritance within family members for more than two generations, and an onset earlier than 65 years old $[4,5]$. More than 400 mutations have been reported on these three genes, but PSEN1 harbors the most mutations, which are also associated with the youngest age at onset with affected individuals typically being 30-50 years old [4, 6-8]. In fact, PSEN1 mutations have also been reported in late-onset AD [9]. Even though ADAD is rare $(<0.5 \%$ of all $A D$ cases) [10], these cases have provided unique insights into the pathobiology of the disease, especially the formulation of the amyloid hypothesis: that accumulation of amyloid-beta aggregates initiates the pathologic process of AD. All three ADAD-causing genes are part of the amyloidbeta processing pathway. However, neuropathological studies have shown that there are common and distinct pathological characteristics [11]. Both $A D A D$ and $A D$ present neuronal loss, neurofibrillary tangles, amyloid plaques and cerebral amyloid angiopathy among others, but ADAD show, for example, cottonwool plaques, more severe cerebral amyloid angiopathy, more common intracerebral hemorrhage or higher abundance of Lewy bodies $[5,12]$.

Recently, studies screening the whole genome or the brain transcriptome have been instrumental in elucidating downstream genes and pathways implicated in disease, highlighting the importance of studying AD beyond the amyloid pathway [13-18]. However, most of these studies have been focused 
medRxiv preprint doi: https://doi.org/10.1101/2021.10.29.21265617; this version posted October 30, 2021. The copyright holder for this preprint (which was not certified by peer review) is the author/funder, who has granted medRxiv a license to display the preprint in perpetuity.

It is made available under a CC-BY-NC-ND 4.0 International license .

on sporadic AD, so their findings cannot always be extrapolated to Mendelian forms of AD; differences between these two forms of the disease are well known $[5,12,19]$. Several studies focused on ADAD have been limited to genetic studies focused on families $[6,20,21]$ and animal studies aiming to understand the amyloid cascade hypothesis [22]. Studies involving large diverse ADAD cohorts are limited.

Circular RNAs are a family of non-coding RNAs that result from backsplicing events (the 3' end of the transcript links covalently to the $5^{\prime}$ forming a loop) [23, 24]. The knowledge of circular RNAs is still limited, but it is thought that they are implicated in the regulation of microRNAs via sequestration, leading to a loss of function of the microRNA [20, 23-25]. Circular RNAs are highly expressed in the nervous system and especially in synapses [20]. Dysregulation of circular RNAs has already been shown for several central nervous diseases, including AD, Parkinson's disease, and traumatic brain injury [20, 25-27]. CircRNA were systematically screened in brain samples from AD compared to controls [20]. They successfully identified more than 100 circRNAs associated with AD status and disease severity measured by Braak neurofibrillary tangles (NFT) and Clinical Dementia Rating (CDR $\left.{ }^{\circledast}\right)$ [28]. When subsetting the analyses to ADAD, 236 circRNAs were found to be dysregulated; 56 of them independently of the severity measured by Braak NFT The circRNAs associated with both ADAD and AD showed larger effect sizes in ADAD than in AD. However, no specific analyses regarding the circular forms of the ADAD genes were performed. In this study, we used bulk RNA-seq to postmortem parietal cortex samples from controls, sporadic AD, and ADAD, we investigated the gene expression profiles of linear and circular transcripts of the ADAD genes to determine their possible involvement in the pathobiology of ADAD.

\section{2.- Methods}

\section{1-Study Population}


medRxiv preprint doi: https://doi.org/10.1101/2021.10.29.21265617; this version posted October 30, 2021. The copyright holder for this preprint (which was not certified by peer review) is the author/funder, who has granted medRxiv a license to display the preprint in perpetuity.

It is made available under a CC-BY-NC-ND 4.0 International license .

The discovery phase included bulk RNA-seq data from parietal cortex samples from non-Hispanic white (NHW) participants: 18 ADAD participants from the Dominantly Inherited Alzheimer Network (DIAN) (14 PSEN1 and four APP mutation carriers), 59 sporadic AD participants and ten control participants from the Knight-ADRC at Washington University in Saint Louis. The replication phase included four ADAD cases from DIAN (two PSEN1, one PSEN2, and one APP mutation carriers), and 215 sporadic AD cases and 15 controls from the Knight-ADRC (Table 1). Finally, we leveraged the Mount Sinai Brain Bank (MSBB) dataset (syn3157743) for replication of the sporadic AD findings (Supplementary Table 1). MSBB contains brain RNA-seq data from different brain regions. From Brodmann area (BM) 10 (frontal pole): 143 AD, 29 Controls; from BM22 (superior temporal gyrus): 134 AD, 26 Controls; from BM36 (parahippocampal gyrus): 123 AD, 24 Controls; from (BM) 44 (inferior frontal gyrus): 132 AD, 25 Controls.

\section{2- Library Preparation and Sequencing}

The data generation for the discovery dataset has been previously published $[20,21]$. We followed the same protocol to generate the replication dataset. Briefly, total RNA was obtained from frozen parietal cortex tissue using the Tissue Lyser LT and RNeasy Mini Kit (Qiagen). After quality control, libraries were generated using TruSeq Stranded Total RNA Sample Prep with Ribo-Zero Gold kit (Illumina). Eighty million $2 \times 150 \mathrm{bp}$ reads were generated on average for each sample using an Illumina HiSeq 4000 . For the replication dataset, we obtained the RNA from frozen brain tissue with the Maxwell RSC simplyRNA tissue kit (Promega). After quality control, TruSeq Stranded Total RNA Sample Prep with Ribo-Zero Gold kit (Illumina) was used to generate the libraries. Thirty-five million $2 \times 150 \mathrm{bp}$ reads were generated on average for each sample using an Illumina NovaSeq 6000.

\section{3- RNA-seq Quality Control, Alignment, and Circular RNAs detection}


medRxiv preprint doi: https://doi.org/10.1101/2021.10.29.21265617; this version posted October 30, 2021. The copyright holder for this preprint (which was not certified by peer review) is the author/funder, who has granted medRxiv a license to display the preprint in perpetuity. It is made available under a CC-BY-NC-ND 4.0 International license .

Both datasets were processed and aligned separately following similar pipelines as the ones previously published by our group [20, 21]. Genome reference and gene models were selected following the $\begin{array}{lll}\text { TOPMed } & \text { pipeline } & \text { (https://github.com/broadinstitute/gtex- }\end{array}$ pipeline/blob/master/TOPMed_RNAseq_pipeline.md). Reference genome GRCh38 and GENCODE 33 annotation, including the addition of ERCC spike-in annotations were used. We excluded ALT, HLA, and Decoy contigs from the reference genome due to the lack of RNA-seq tools that allow proper handling of these regions. To obtain the linear counts we followed standard guidelines. Briefly, the raw reads were aligned to the human reference genome (GRCh38) using STAR (v.2.7.1a) [29]. We evaluated the quality of the alignment using sequencing metrics such as reads distribution, ribosomal content or alignment quality provided by STAR [29] using Picard tools (v.2.8.2) [30]. Gene expression was quantified using Salmon (v.1.2.0) [31] and the GENCODE reference genome (GRCh38). All transcripts or genes with less than ten reads in more than $90 \%$ of the individuals were removed.

To obtain the circular RNA counts, all raw reads were first aligned to the human reference genome (GRCh38) using STAR [29] in chimeric alignment mode. The remaining alignment parameters were selected specifically for circular RNA detection as suggested by the developers of the circular RNA calling software DCC [32]. Circular RNA detection, annotation and quantification was performed using DCC (v.0.4.8). We excluded any circRNA that had missing counts in more than $25 \%$ of the samples. As part of the general quality control, circRNAs that were not present in at least three samples, with a minimum of three counts in at least one of them, were removed. Additionally, we removed any circRNA with missing counts in more than $75 \%$ of the samples. Then we proceeded to extract the linear and circular forms corresponding to the three ADAD genes (APP, PSEN1 and PSEN2) from each dataset. For all three datasets, only the circPSEN1 could be detected; circAPP and circPSEN2 were not detected. As a consequence, the analyses were focused on linear PSEN1 and circPSEN1. The species of circPSEN1 varied depending on the dataset and the brain region for the MSBB. Overall, seven circPSEN1 species were 
medRxiv preprint doi: https://doi.org/10.1101/2021.10.29.21265617; this version posted October 30, 2021. The copyright holder for this preprint (which was not certified by peer review) is the author/funder, who has granted medRxiv a license to display the preprint in perpetuity.

It is made available under a CC-BY-NC-ND 4.0 International license .

detected by DCC; but four of them (hsa_circ_0008521, hsa_circ_0003848, hsa_circ_0007013, hsa_circ_0002564) were commonly detected in all three datasets and most of the brain areas (except hsa_circ_0008521 for BM10, hsa_circ_0007013 for BM22 and BM44).

\section{4- Statistical Analyses}

We tested if the levels of circular PSEN1 (circPSEN1) and linear PSEN1 were different among groups by comparing $A D$ and control participants, $A D A D$ and $A D$ participants, and ADAD and control participants in both the discovery and the replication datasets. The same analysis of circPSEN1 was also performed between sporadic AD participants and control subjects in the MSBB dataset (no ADAD participants were available in the MSBB dataset). We also investigated which specific cirCPSEN1 transcripts were predominant in each group and dataset. After normalization of the counts, differential expression (DE) analyses were performed specifically for circPSEN1 and linear PSEN1 using DEseq2 version 1.22.2 [33] to determine significance. Any association with $p$-value $<0.05$ was considered significant. All DE analyses were adjusted for postmortem interval (PMI), RNA quality as measured by median transcript integrity number (TIN) [34] and sex. We also tested if circPSEN1 was associated to Braak NFT or age at death to investigate if our findings were driven by disease severity as previously descrived [20]. Briefly, the variable of interest was added to the model to evaluate the effect on the p-value, effect size and direction of the circPSEN1 association.

Due to the moderate size of our sample, we combined the discovery and replication datasets, since they were processed using the same pipeline, and performed a joint analysis adding dataset to the model to adjust for possible differences in the DE analysis.

\section{5.- In-Silico Functional Study}

To investigate the biological function of circPSEN1, we accessed the Circular RNA Interactome website [35] to predict which miRNAs have the potential to target any of the circPSEN1 species identified in our 
medRxiv preprint doi: https://doi.org/10.1101/2021.10.29.21265617; this version posted October 30, 2021. The copyright holder for this preprint (which was not certified by peer review) is the author/funder, who has granted medRxiv a license to display the preprint in perpetuity.

It is made available under a CC-BY-NC-ND 4.0 International license .

datasets. Then, we used the DIANA mirPath software version 3 [36] to identify which genes and pathways were regulated by the identified miRNA using the microT-CDS algorithm and the Kyoto Encyclopedia of Genes and Genomes (KEGG). Finally, we investigated if any of the common genes listed in the pathways identified by the DIANA mirPath software version 3 were differentially expressed in the ADAD cases compared to controls or sporadic AD cases in the discovery dataset.

\section{6.- Discriminative Ability of cirCPSEN1}

To evaluate if cirCPSEN1 can discriminate ADAD from the other brains, we used three binomial regression models built using three different circPSEN1 normalized counts: aggregate counts, hsa_circ_0008521, and hsa_circ_0003848 counts to classify ADAD vs. controls, ADAD vs. AD, and AD vs. controls in both the discovery and the replication datasets separately. We used the discovery dataset to train the models, and the replication dataset to validate them. We then evaluated the model performance through receiver operating characteristic curves (ROCs) and areas under the ROC curve (AUCS). The binomial regression models and the receiver operating characteristic curve analyses were performed using R packages stats version 3.5.2 and ROCR version 1.0-7.

\section{3.- Results}

\section{1-circPSEN1 is more abundant in ADAD than Sporadic AD and Controls}

The circPSEN1 normalized counts were significantly higher in ADAD cases ( $N=18)$ compared to controls $\left(N=10 ; p=1.61 \times 10^{-04}, \log _{2} F C=0.81\right)$ and sporadic $A D$ cases $\left(N=59 ; p=5.00 \times 10^{-03}, \log _{2} F C=0.52\right)$, but did not differ between $A D$ cases and controls $\left(p=0.21, \log _{2} F C=0.29\right.$ ) (Table 2 and Figure $\left.1 A\right)$ in the discovery dataset. The trend was also observed in the replication dataset in all three comparisons $\left(\log _{2} \mathrm{FC}_{\mathrm{ADADvsCO}}=0.65 ; \log _{2} \mathrm{FC}_{\mathrm{ADADvsAD}}=0.64 ; \log _{2} \mathrm{FC}_{\mathrm{ADvsCO}}=0.10\right)$ (Table 2 and Figure $\left.1 \mathrm{~B}\right)$. Due to the limited sample size of the ADAD group, we do not have enough statistical power to detect differences in the replication dataset (24 ADAD samples are required to have $80 \%$ power with a probability of type I error 
medRxiv preprint doi: https://doi.org/10.1101/2021.10.29.21265617; this version posted October 30, 2021. The copyright holder for this preprint (which was not certified by peer review) is the author/funder, who has granted medRxiv a license to display the preprint in perpetuity.

It is made available under a CC-BY-NC-ND 4.0 International license .

of 0.05$)$. Consequently, we performed a joint analysis of the two datasets. A more significant association was found in the join analyses than in the discovery dataset, indicating that the higher expression level of cirCPSEN1 specific to ADAD than sporadic $A D$ cases and controls $\left(p_{A D A D v s C O}=9.08 \times 10^{-05}, \log _{2} F C=0.79\right.$; $p_{A D A D v s A D}=2.00 \times 10^{-03}, \log _{2} F C=0.58 ; p_{A D v s C O}=0.44, \log _{2} F C=0.14 ;$ Table 2$)$.

We leveraged the MSBB dataset to confirm that there were no differences between the normalized counts of circPSEN1 between AD cases and controls. circPSEN1 is not differentially expressed in any of the four brain regions (BM10, BM22, BM36, BM44) available in the MSBB dataset (Supplementary Figure 1 and supplementary Table2), which is consistent with our finding that higher circPSEN1 expression is specific to ADAD cases.

Similar to RNA-seq, circPSEN1 total count is the result of the addition of all the counts from the different species of circPSEN1. We investigated if the differences observed between ADAD and AD or controls were the result of an overall increase or the increase of a specific species. Seven circPSEN1 species were found in the discovery and replication dataset (Table 3). All of them are exon derived except one that is intron-exon derived (cirCPSEN1- 73147795-73165413). Considering the four species commonly detected in both datasets, the most abundant are hsa_circ_0008521, hsa_circ_0003848, and hsa_circ_0002564; being the first two species significantly different between $A D A D$ and $A D\left(p=6.56 \times 10^{-03}, 0.041\right.$, $\log _{2} \mathrm{FC}=0.69,0.54$, for joint dataset) and $\mathrm{ADAD}$ and Controls $\left(\mathrm{p}=1.50 \times 10^{-04}, 7.00 \times 10^{-03}, \log _{2} \mathrm{FC}=1.02,0.77\right.$, for joint dataset). Hsa_circ_0002564 was only significantly different between ADAD and AD ( $p=0.01$, $\log _{2} \mathrm{FC}=0.60$, for joint dataset). No significant differences were found between disease status for hsa_circ_0007013 (Table 3 and Supplementary Figure 2), suggesting that hsa_circ_008521 and hsa_circ_0003848 are driving the association. No significant differences were found between AD and controls for the two species detected in the MSBB dataset in any brain region (Supplementary Table 2). We also investigated the relationship among these three species using correlation tests. We observed high correlation between hsa_circ_0008521 and hsa_circ_0003848 in the discovery $\left(r^{2}=0.77, p=2.20 \times 10\right.$ 
$\left.{ }^{16}\right)$, replication $\left(r^{2}=0.39, p=3.56 \times 10^{-12}\right)$, and MSBB (BM22 $-r^{2}=0.42, p=3.44 \times 10^{-08} \mid B M 36-r^{2}=0.58$, $\left.p=7.79 \times 10^{-15} \mid B M 44-r^{2}=0.71, p=2.2 \times 10^{-16}\right)$ datasets. Hsa_circ_0002564 shows weak correlations with the other two circPSEN1 species even though some of them are nominally significant (with hsa_circ_0008521 only in the discovery dataset $-r^{2}=0.24, p=0.03$, and with hsa_circ_0003848 in the discovery $-r^{2}=0.26, p=0.01$ and in the BM22 of the MSBB dataset $\left.-r^{2}=0.31, p=8.15 \times 10^{-05}\right)$. This results suggest that hsa_circ_0008521 and hsa_circ_0003848 seem to share the same mechanism of dysregulation, which might be different from hsa_circ_0002564.

To ensure that the association was not driven by disease severity or age at death, we tested if Braak NFT score or age at death were influencing the association of circPSEN1 with ADAD. We observed no significant changes on the results (Supplementary Table 3), suggesting that these findings are not due to pathology severity or the age of the individual.

\section{2-Circular PSEN1 is independent from linear PSEN1}

We then investigated if the association between ADAD and circPSEN1 was also observed in the linear form of PSEN1. No significant differences were found (Table 2, Figures 1C and 1D).

We then tested the independency of the normalized counts for the linear and circular forms of PSEN1. significant correlation was observed for the ADAD individuals or the controls (Supplementary Figure 3).

The correlation between the linear PSEN1 and the circPSEN1 was weak $\left(\mathrm{R}_{\text {Discovery }}=0.40 ; \mathrm{R}_{\text {Replication }}=0.23\right)$, even though it was nominally significant $\left(p_{\text {Discovery }}=1.04 \times 10^{-03}, p_{\text {Replication }}=1.04 \times 10^{-03}\right)$ in the AD group. To assess if this correlation was affecting our results in the AD group, linear PSEN1 was added to the differential expression analysis as previously described [37]. The changes of circPSEN1 were still significant $\left(p=6.88 \times 10^{-04}\right)$, even when adjusting for linear PSEN1. This result suggests, that even though the correlation of linear and circular PSEN1 was nominally significant, the linear and circular forms are 
medRxiv preprint doi: https://doi.org/10.1101/2021.10.29.21265617; this version posted October 30, 2021. The copyright holder for this preprint (which was not certified by peer review) is the author/funder, who has granted medRxiv a license to display the preprint in perpetuity.

It is made available under a CC-BY-NC-ND 4.0 International license .

independent. Similar results were observed for correlation analyses using for PSEN1 species against linear counts (data not shown).

3.3-ADAD individuals have higher circPSEN1 counts independently of the mutation

ADAD mutations are most prevalent in PSEN1 among individuals in both the discovery and the replication datasets. Thus, we evaluated if the high expression levels of circPSEN1 were unique to PSEN1 mutation carriers. In the joint dataset (Figure 2A), the normalized counts of circPSEN1 between PSEN1 mutation carriers $(\mathrm{N}=16)$ and $A P P$ mutation carriers $(\mathrm{N}=5)$ are not significantly different $(\log 2 \mathrm{FC}=0.245$, $\mathrm{p}=0.414)$. When compared to $A D$ cases $(\mathrm{N}=274)$ or controls $(\mathrm{N}=25)$, PSEN1 mutation carriers showed increased levels of circPSEN1 ( $\log _{2} \mathrm{FC}=0.604, \mathrm{p}=0.005$, and $\left.\log _{2} \mathrm{FC}=0.778, \mathrm{p}=8.299 \times 10-04\right)$. APP mutation carriers also showed higher counts of circPSEN1 when compared to controls $\left(\log _{2} \mathrm{FC}=0.658, \mathrm{p}=0.012\right)$. Due to the limited sample size of PSEN2 mutation carriers ( $N=1)$, no statistical test was performed. No differences were found among mutations carriers regarding linear PSEN1 normalized counts (Figure 2B).

\section{4-In-silico analyses functional annotation}

We found the three most abundant species of circPSEN1 in our samples to be hsa_circ_0008521, hsa_circ_0003848, and hsa_circ_0002564, with the first two most likely driving the overall signal. CircRNAs have been reported to regulate gene expression by sequestering miRNA. Because the biological function of these circPSEN1 species has not been described, we explored if the biological function of circPSEN1 might be elucidated by those miRNAs targeted to them. Using the Targetscan prediction tool[38] from the Circlnteractome database [35], we identified 26 miRNAs that could potentially target to the three most abundant species of circPSEN1. We used them as input in the microT-CDS tool of the DIANA mirPath v.3 software to elucidate which pathways are potentially regulated by the identified miRNA. Several pathways were found significantly associated with these 26 miRNAs: axon guidance $\left(p=3.39 \times 10^{-07}\right)$; hippo signaling pathway $\left(p=7.38 \times 10^{-07}\right)$; lysine degradation 
medRxiv preprint doi: https://doi.org/10.1101/2021.10.29.21265617; this version posted October 30, 2021. The copyright holder for this preprint (which was not certified by peer review) is the author/funder, who has granted medRxiv a license to display the preprint in perpetuity.

It is made available under a CC-BY-NC-ND 4.0 International license .

$\left(p=2.48 \times 10^{-05}\right)$; and Wnt signaling pathway $\left(p=5.58 \times 10^{-04}\right)$ among other KEGG pathways (Supplementary

Table 4). We identified 31 genes that were common in the top ten KEGG pathways (Supplementary

Table 5); the counts of two of them were found significantly lower in ADAD brains compared to AD

brains. FDZ4 and RAF1 were nominally significant in the discovery $\left(p=0.037 ; p=5.55 \times 10^{-04}\right)$ and replication ( $p=0.001 ; p=0.039)$ datasets. Both genes are related to the transmission of chemical signals between the cell surface and the nucleus.

\section{$\underline{\text { 3.5-Circular PSEN1 normalized counts can discriminate ADAD }}$}

The predictive ability of circPSEN1 counts (aggregate, hsa_circ_0008521, and hsa_circ_0003848) was evaluated using ROCs and AUCs (Supplementary Figure 4). Aggregated and individual normalized counts of circPSEN1 show no predictive ability for AD vs. CO. However, circPSEN1 showed good predictive power for ADAD vs. AD. The AUC for the aggregated counts in the discovery dataset was 0.73; that in the replication dataset was 0.79 . When we evaluated the predictive power of the two circPSEN1 species separately, hsa_circ_0008521 seemed to have slightly better predictive power than hsa_circ_0003848. Yet, the aggregate counts of circPSEN1 seemed to show a more robust discriminative power, which generated similar AUCs across datasets.

The discriminative power of circPSEN1 increased when we attempted to classify ADAD vs. CO, with an AUC of 0.82 in the discovery dataset and an AUC of 0.85 in the replication dataset for the aggregated counts of cirCPSEN1. The trends were very consistent for both datasets for all three predictions despite the differences in sample size. This result suggests that, even though the most abundant circPSEN1 species seem to have more discriminative power, the less abundant ones (hsa_circ_0007013, hsa_circ_0002564, hsa_circ_0008218, hsa_circ_0032509) are also contributing since the discriminative power of the aggregate counts is more stable in the two datasets.

\section{4.- Discussion}


medRxiv preprint doi: https://doi.org/10.1101/2021.10.29.21265617; this version posted October 30, 2021. The copyright holder for this preprint (which was not certified by peer review) is the author/funder, who has granted medRxiv a license to display the preprint in perpetuity.

It is made available under a CC-BY-NC-ND 4.0 International license .

In this study, we provide evidence that the transcriptional signatures differ between ADAD and AD brains. By analyzing the largest dataset to date of ADAD brains, we have found that circPSEN1 expression is increased in ADAD brains but not in AD cases or controls, a result which is independent of age and disease severity (as measured by Braak NFT score). Our results show that this increased expression is not specific to PSEN1 mutation carriers, as similar results were observed in APP mutation carriers, or due to linear PSEN1, suggesting a biological mechanism specific to the cirCPSEN1.

A previous study [20], demonstrated that expression changes of circRNAs in pre-symptomatic AD, sporadic $A D$, and $A D A D$ are different and not always related to severity of the disease. They found more than 100 circRNAs dysregulated in the context of $A D$, demonstrating the involvement of circRNA in the pathobiology of AD. In fact, they found even more circRNA dysregulated in their comparison of ADAD participants versus controls. In the present study we add evidence to the importance of the dysregulation of circRNAs. Dube et al, identified that circRNAs that were dysregulated in both AD and ADAD, presented with larger effect sizes in ADAD. In here, we found that circPSEN1 that is related to the amyloid pathway is uniquely dysregulated in ADAD participants. This emphasizes the importance of studying not only the molecular similarities between $A D$ and $A D A D$, but also the differences.

It has been demonstrated that circular RNAs are generated through the spliceosome, suggesting that additional to the miRNA regulation through their sponge function, circular RNA generation is one of the mechanisms that regulates the production of linear RNA [39]. On top of that, spliceosomal proteins have been reported to aggregate with tau tangles [40] and to be down-regulated in the presence of amyloidbeta $_{42}$ [41]. The production of circPSEN1 could be due to the mutations present in PSEN1 via spliceosome alterations. Among the PSEN1 mutations in this study, p.H163R is located at the boundaries of hsa_circ_0002564. This might explain the dysregulation of this particular circular RNA. However, this mutation was present in only four of the ADAD brain samples, suggesting that other regulatory events are taking place in the ADAD individuals unrelated to this mutation. In fact, previous studies have 
medRxiv preprint doi: https://doi.org/10.1101/2021.10.29.21265617; this version posted October 30, 2021. The copyright holder for this preprint (which was not certified by peer review) is the author/funder, who has granted medRxiv a license to display the preprint in perpetuity.

It is made available under a CC-BY-NC-ND 4.0 International license .

demonstrated that introns regulate the biogenesis of circular RNA. Given that most of the PSEN1 mutations are located within the exons, it is likely that this might not be the biological explanation.

Our in-silico functional analysis predicted 26 miRNAs that could bind the three abundant circPSEN1 species. These 26 miRNAs are significantly associated with several pathways, including wnt, hippo and axon guidance pathways that have been previously related to the development of $A D$ and to neuroinflammation [42-45]. Among the 26 identified miRNAs, miR-144 has previously been associated with AD [46]; in fact, miR-144-3p targets $A P P$, significantly inhibiting protein expression [47]. The overexpression of miR-433 targets JAK2 (janus kinase 2) which contributes to the progression of AD by inhibition of amyloid-beta-induced neuronal viability [48]. Additionally, miR-566 [49] and miR885-5p [50] were also found to be dysregulated in AD. Finally, miR-655 inhibited the inflammatory response of microglia by targeting TREM2 (triggering receptor expressed on myeloid 2) [51], which is known to affect amyloid and tau pathologies. Our finding adds evidence to the fact that AD is not restricted to neurons but involves several mechanisms including inflammation [52]. Given the involvement of microglia in the inflammatory process, axon guidance [53], and the role of wnt pathway [45], the presence of cirCPSEN1 might be originating from the microglia. Analyses of circPSEN1 using publicly available RNAseq data from IPSCS [54] (data not shown) showed no differences between mutation carriers and isogenic corrected cells. Additionally, previous studies have shown that the neuronal proportion in ADAD brains seems to be lower compared to AD [21]. Together, this suggests that the cirCPSEN1 association described in here might not have a neuronal origin.

cirCPSEN1 might be a regulatory factor located at the top hierarchical levels of the dysregulation of the amyloid-beta pathway and leading to the neuroinflammatory status. Our results show that circPSEN1 is dysregulated in all ADAD cases, independent of the specific mutation. However, due to the limited sample size of PSEN2 and APP carriers, we cannot disregard the possibility that this alteration is unique to PSEN1 mutation carriers. 
Additional analyses to understand the biological function of circPSEN1 and its relationship with PSEN1 are needed, along with the study of circular and linear forms of PSEN2 and APP in mutation carriers to elucidate the biological consequences of circular RNAs in ADAD in comparison to AD. If further replicated, circPSEN1 might be targeted to diminish neuroinflammation in ADAD individuals to delay the onset of the disease or slow down its progression.

This study includes the largest sample of ADAD brains analyzed to date. However, it is still a study with limited sample size, therefore limiting the statistical power of this analysis. Although our findings are novel and possibly biologically relevant, due to the limited knowledge about circular RNAs and their biological function, along with the relationship between linear and circular forms of the same gene, we cannot claim any causal involvement of circPSEN1 with ADAD or AD.

\section{5.- Conclusions}

In conclusion, our circPSEN1 differential expression analysis has shown significant differences in the expression of circPSEN1 that are unique to ADAD, and independent of gene mutation. Due to the biological function previously ascribed to circular RNAs and our in-silico analyses, we hypothesize that this finding might be related to neuroinflammatory events that lead or that are caused by the accumulation of amyloid-beta. Future studies aimed at understanding the biological function of circPSEN1 might lead to a better understanding of its pathological involvement with ADAD and its potential as drug-target.

\section{6.- Declarations}

Ethics approval and consent to participate: The Institutional Review Boards of Washington University School of Medicine in St. Louis approved the study, and research was carried out in accordance with the approved protocols. Written informed consent was obtained from all participants or their family members. 
medRxiv preprint doi: https://doi.org/10.1101/2021.10.29.21265617; this version posted October 30, 2021. The copyright holder for this preprint (which was not certified by peer review) is the author/funder, who has granted medRxiv a license to display the preprint in perpetuity.

It is made available under a CC-BY-NC-ND 4.0 International license .

Consent for publication: All authors read and approved the final manuscript.

Availability of data and materials: Discovery dataset data corresponding to the participants who enrolled in the Knight-ADRC can be downloaded at the NIAGADS Knight ADRC collection (NG00083). Additional Knight-ADRC participants and DIAN data is available upon request to qualified researchers. Finally, MSBB dataset is publicly available in Synapse (syn3159438).

Competing Interests: The authors report no competing interests in relation to this manuscript.

Funding: This work was supported by grants from the National Institutes of Health (K99-AG062723 (LI), R01AG044546 (CC), P01AG003991, RF1AG053303 (CC), R01AG058501 (CC), U01AG058922 (CC), K01AG046374, and R01HL119813), the Alzheimer's Drug Discovery Foundation (GDAPB-2018072015632), Bright Focus Foundation (A2021033S) and Department of Defense (W81XWH2010849). The recruitment and clinical characterization of participants who enrolled in the Knight-ADRC was supported by NIH P30 AG066444

Data collection and sharing for this project was supported by The Dominantly Inherited Alzheimer Network (DIAN, U19AG032438) funded by the National Institute on Aging (NIA), the Alzheimer's Association (SG-20-690363-DIAN), the German Center for Neurodegenerative Diseases (DZNE), Raul Carrea Institute for Neurological Research (FLENI), Partial support by the Research and Development Grants for Dementia from Japan Agency for Medical Research and Development, AMED, and the Korea Health Technology R\&D Project through the Korea Health Industry Development Institute (KHIDI), Spanish Institute of Health Carlos III (ISCIII), Canadian Institutes of Health Research (CIHR), Canadian Consortium of Neurodegeneration and Aging, Brain Canada Foundation, and Fonds de Recherche du Québec-Santé. 
Author's contributions: $\mathrm{LI}$ and HHC conceived and wrote this article. AE provided and QCed the data.

HHC and CW performed the analyses. AE, CW, MVF, JB, KB, FW, CE, JCM, RJP, RJB, EMD, CX, AG, MF, JC, PRS, $\mathrm{HC}, \mathrm{OH}$ and $\mathrm{CC}$ discussed the project, revised the manuscript and provided critical feedback.

Acknowledgments: We thank all the participants and their families along with the institutions and all the staff who provided brain tissue, without whom this study would not have been possible. This work was supported by access to equipment made possible by the Hope Center for Neurological Disorders, the Neurogenomics and Informatics Center (NGI: https://neurogenomics.wustl.edu/) and the Departments of Neurology and Psychiatry at Washington University School of Medicine.

This manuscript has been reviewed by DIAN Study investigators for scientific content and consistency of data interpretation with previous DIAN Study publications. We acknowledge the altruism of the participants and their families and contributions of the DIAN research and support staff at each of the participating sites for their contributions to this study.

\section{Conflict of interest}

The funders of the study had no role in the collection, analysis, or interpretation of data; in the writing of the report; or in the decision to submit the paper for publication. CC is a member of the advisory board of Vivid genetics, Halia Therapeutics and ADx Healthcare and has received research support from Biogen, EISAI, Alector and Parabon. The rest of the authors report no conflict of interest. 
medRxiv preprint doi: https://doi.org/10.1101/2021.10.29.21265617; this version posted October 30, 2021. The copyright holder for this preprint (which was not certified by peer review) is the author/funder, who has granted medRxiv a license to display the preprint in perpetuity. It is made available under a CC-BY-NC-ND 4.0 International license .

\section{References}

1. https://www.alz.org/media/documents/alzheimers-facts-and-figures-infographic.pdf.

2. LaFerla FM, Oddo S: Alzheimer's disease: Abeta, tau and synaptic dysfunction. Trends in molecular medicine 2005, 11:170-176.

3. Ibanez L, Cruchaga C, Fernandez MV: Advances in Genetic and Molecular Understanding of Alzheimer's Disease. Genes 2021, 12.

4. Lin YS, Cheng CY, Liao YC, Hong CJ, Fuh JL: Mutational analysis in familial Alzheimer's disease of Han Chinese in Taiwan with a predominant mutation PSEN1 p.Met146lle. Sci Rep 2020, 10:19769.

5. Bateman RJ, Aisen PS, De Strooper B, Fox NC, Lemere CA, Ringman JM, Salloway S, Sperling RA, Windisch $\mathrm{M}$, Xiong $\mathrm{C}$ : Autosomal-dominant Alzheimer's disease: a review and proposal for the prevention of Alzheimer's disease. Alzheimer's research \& therapy 2011, 3:1.

6. Bekris LM, Yu CE, Bird TD, Tsuang DW: Genetics of Alzheimer disease. J Geriatr Psychiatry Neurol 2010, 23:213-227.

7. Hsu S, Gordon BA, Hornbeck R, Norton JB, Levitch D, Louden A, Ziegemeier E, Laforce R, Jr., Chhatwal J, Day GS, et al: Discovery and validation of autosomal dominant Alzheimer's disease mutations. Alzheimer's research \& therapy 2018, 10:67.

8. Karch CM, Hernandez D, Wang JC, Marsh J, Hewitt AW, Hsu S, Norton J, Levitch D, Donahue T, Sigurdson W, et al: Human fibroblast and stem cell resource from the Dominantly Inherited Alzheimer Network. Alzheimer's research \& therapy 2018, 10:69.

9. Fernandez MV, Kim JH, Budde JP, Black K, Medvedeva A, Saef B, Deming Y, Del-Aguila J, Ibanez L, Dube $U$, et al: Analysis of neurodegenerative Mendelian genes in clinically diagnosed Alzheimer Disease. PLoS Genet 2017, 13:e1007045.

10. Ryan NS, Nicholas JM, Weston PSJ, Liang Y, Lashley T, Guerreiro R, Adamson G, Kenny J, Beck J, Chavez-Gutierrez L, et al: Clinical phenotype and genetic associations in autosomal dominant familial Alzheimer's disease: a case series. The Lancet Neurology 2016, 15:1326-1335.

11. Ringman JM, Monsell S, Ng DW, Zhou Y, Nguyen A, Coppola G, Van Berlo V, Mendez MF, Tung S, Weintraub S, et al: Neuropathology of Autosomal Dominant Alzheimer Disease in the National Alzheimer Coordinating Center Database. Journal of neuropathology and experimental neurology 2016, 75:284-290.

12. Boon BDC, Bulk M, Jonker AJ, Morrema THJ, van den Berg E, Popovic M, Walter J, Kumar S, van der Lee $\mathrm{SJ}$, Holstege $\mathrm{H}$, et al: The coarse-grained plaque: a divergent Abeta plaque-type in early-onset Alzheimer's disease. Acta neuropathologica 2020, 140:811-830.

13. Cignarella F, Filipello F, Bollman B, Cantoni C, Locca A, Mikesell R, Manis M, Ibrahim A, Deng L, Benitez $B A$, et al: TREM2 activation on microglia promotes myelin debris clearance and remyelination in a model of multiple sclerosis. Acta neuropathologica 2020, 140:513-534.

14. Guerreiro R, Wojtas A, Bras J, Carrasquillo M, Rogaeva E, Majounie E, Cruchaga C, Sassi C, Kauwe JS, Younkin S, et al: TREM2 variants in Alzheimer's disease. N Engl J Med 2013, 368:117-127.

15. Ewers M, Franzmeier N, Suarez-Calvet M, Morenas-Rodriguez E, Caballero MAA, Kleinberger G, Piccio L, Cruchaga C, Deming Y, Dichgans $M$, et al: Increased soluble TREM2 in cerebrospinal fluid is associated with reduced cognitive and clinical decline in Alzheimer's disease. Science translational medicine 2019, 11.

16. Deming Y, Filipello F, Cignarella F, Cantoni C, Hsu S, Mikesell R, Li Z, Del-Aguila JL, Dube U, Farias FG, et al: The MS4A gene cluster is a key modulator of soluble TREM2 and Alzheimer's disease risk. Science translational medicine 2019, 11. 
medRxiv preprint doi: https://doi.org/10.1101/2021.10.29.21265617; this version posted October 30, 2021. The copyright holder for this preprint (which was not certified by peer review) is the author/funder, who has granted medRxiv a license to display the preprint in perpetuity.

It is made available under a CC-BY-NC-ND 4.0 International license .

17. Del-Aguila JL, Li Z, Dube U, Mihindukulasuriya KA, Budde JP, Fernandez MV, Ibanez L, Bradley J, Wang F, Bergmann K, et al: A single-nuclei RNA sequencing study of Mendelian and sporadic AD in the human brain. Alzheimer's research \& therapy 2019, 11:71.

18. Del-Aguila JL, Benitez BA, Li Z, Dube U, Mihindukulasuriya KA, Budde JP, Farias FHG, Fernandez $M V$, lbanez $L$, Jiang $S$, et al: TREM2 brain transcript-specific studies in AD and TREM2 mutation carriers. Molecular neurodegeneration 2019, 14:18.

19. Ringman JM, Goate A, Masters CL, Cairns NJ, Danek A, Graff-Radford N, Ghetti B, Morris JC, Dominantly Inherited Alzheimer N: Genetic heterogeneity in Alzheimer disease and implications for treatment strategies. Curr Neurol Neurosci Rep 2014, 14:499.

20. Dube U, Del-Aguila JL, Li Z, Budde JP, Jiang S, Hsu S, Ibanez L, Fernandez MV, Farias F, Norton J, et al: An atlas of cortical circular RNA expression in Alzheimer disease brains demonstrates clinical and pathological associations. Nature neuroscience 2019, 22:1903-1912.

21. Li Z, Del-Aguila JL, Dube U, Budde J, Martinez R, Black K, Xiao Q, Cairns NJ, Dominantly Inherited Alzheimer N, Dougherty JD, et al: Genetic variants associated with Alzheimer's disease confer different cerebral cortex cell-type population structure. Genome Med 2018, 10:43.

22. LaFerla FM, Green KN: Animal models of Alzheimer disease. Cold Spring Harb Perspect Med 2012, 2.

23. Barrett SP, Salzman J: Circular RNAs: analysis, expression and potential functions. Development 2016, 143:1838-1847.

24. Li X, Yang L, Chen LL: The Biogenesis, Functions, and Challenges of Circular RNAs. Molecular cell 2018, 71:428-442.

25. Mehta SL, Dempsey RJ, Vemuganti R: Role of circular RNAs in brain development and CNS diseases. Progress in neurobiology 2020, 186:101746.

26. Ravanidis S, Bougea A, Karampatsi D, Papagiannakis N, Maniati M, Stefanis L, Doxakis E: Differentially Expressed Circular RNAs in Peripheral Blood Mononuclear Cells of Patients with Parkinson's Disease. Movement disorders : official journal of the Movement Disorder Society 2021, 36:1170-1179.

27. Hanan M, Simchovitz A, Yayon N, Vaknine S, Cohen-Fultheim R, Karmon M, Madrer N, Rohrlich TM, Maman M, Bennett ER, et al: A Parkinson's disease CircRNAs Resource reveals a link between circSLC8A1 and oxidative stress. EMBO Mol Med 2020, 12:e13551.

28. Morris JC: The Clinical Dementia Rating (CDR): current version and scoring rules. Neurology 1993, 43:2412-2414.

29. Dobin A, Davis CA, Schlesinger F, Drenkow J, Zaleski C, Jha S, Batut P, Chaisson M, Gingeras TR: STAR: ultrafast universal RNA-seq aligner. Bioinformatics 2013, 29:15-21.

30. http://broadinstitute.github.io/picard/.

31. Patro R, Duggal G, Love MI, Irizarry RA, Kingsford C: Salmon provides fast and bias-aware quantification of transcript expression. Nature methods 2017, 14:417-419.

32. Cheng J, Metge F, Dieterich C: Specific identification and quantification of circular RNAs from sequencing data. Bioinformatics 2016, 32:1094-1096.

33. Love MI, Huber W, Anders S: Moderated estimation of fold change and dispersion for RNA-seq data with DESeq2. Genome biology 2014, 15:550.

34. Wang L, Nie J, Sicotte H, Li Y, Eckel-Passow JE, Dasari S, Vedell PT, Barman P, Wang L, Weinshiboum R, et al: Measure transcript integrity using RNA-seq data. BMC bioinformatics 2016, 17:58.

35. Dudekula DB, Panda AC, Grammatikakis I, De S, Abdelmohsen K, Gorospe M: Circlnteractome: A web tool for exploring circular RNAs and their interacting proteins and microRNAs. RNA biology 2016, 13:34-42. 
medRxiv preprint doi: https://doi.org/10.1101/2021.10.29.21265617; this version posted October 30, 2021. The copyright holder for this preprint (which was not certified by peer review) is the author/funder, who has granted medRxiv a license to display the preprint in perpetuity.

It is made available under a CC-BY-NC-ND 4.0 International license .

36. Vlachos IS, Zagganas K, Paraskevopoulou MD, Georgakilas G, Karagkouni D, Vergoulis T, Dalamagas T, Hatzigeorgiou AG: DIANA-miRPath v3.0: deciphering microRNA function with experimental support. Nucleic Acids Res 2015, 43:W460-466.

37. You X, Vlatkovic I, Babic A, Will T, Epstein I, Tushev G, Akbalik G, Wang M, Glock C, Quedenau C, et al: Neural circular RNAs are derived from synaptic genes and regulated by development and plasticity. Nature neuroscience 2015, 18:603-610.

38. Grimson A, Farh KK, Johnston WK, Garrett-Engele P, Lim LP, Bartel DP: MicroRNA targeting specificity in mammals: determinants beyond seed pairing. Molecular cell 2007, 27:91-105.

39. Ashwal-Fluss R, Meyer M, Pamudurti NR, Ivanov A, Bartok O, Hanan M, Evantal N, Memczak S, Rajewsky N, Kadener S: circRNA biogenesis competes with pre-mRNA splicing. Molecular cell 2014, 56:55-66.

40. Hsieh YC, Guo C, Yalamanchili HK, Abreha M, Al-Ouran R, Li Y, Dammer EB, Lah JJ, Levey Al, Bennett DA, et al: Tau-Mediated Disruption of the Spliceosome Triggers Cryptic RNA Splicing and Neurodegeneration in Alzheimer's Disease. Cell reports 2019, 29:301-316 e310.

41. Nuzzo D, Inguglia L, Walters J, Picone P, Di Carlo M: A Shotgun Proteomics Approach Reveals a New Toxic Role for Alzheimer's Disease Abeta Peptide: Spliceosome Impairment. Journal of proteome research 2017, 16:1526-1541.

42. Inestrosa NC, Montecinos-Oliva C, Fuenzalida M: Wnt signaling: role in Alzheimer disease and schizophrenia. Journal of neuroimmune pharmacology : the official journal of the Society on Neurolmmune Pharmacology 2012, 7:788-807.

43. Zhang L, Qi Z, Li J, Li M, Du X, Wang S, Zhou G, Xu B, Liu W, Xi S, et al: Roles and Mechanisms of Axon-Guidance Molecules in Alzheimer's Disease. Molecular neurobiology 2021, 58:3290-3307.

44. Wang SP, Wang LH: Disease implication of hyper-Hippo signalling. Open biology 2016, 6.

45. Yang Y, Zhang Z: Microglia and Wnt Pathways: Prospects for Inflammation in Alzheimer's Disease. Frontiers in aging neuroscience 2020, 12:110.

46. Keller A, Leidinger P, Vogel B, Backes C, ElSharawy A, Galata V, Mueller SC, Marquart S, Schrauder MG, Strick $R$, et al: miRNAs can be generally associated with human pathologies as exemplified for miR-144. BMC Med 2014, 12:224.

47. Li K, Zhang J, Ji C, Wang L: MiR-144-3p and Its Target Gene beta-Amyloid Precursor Protein Regulate 1-Methyl-4-Phenyl-1,2-3,6-Tetrahydropyridine-Induced Mitochondrial Dysfunction. Molecules and cells 2016, 39:543-549.

48. Wang R, Zhang J: Clinical significance of miR-433 in the diagnosis of Alzheimer's disease and its effect on Abeta-induced neurotoxicity by regulating JAK2. Experimental gerontology 2020, 141:111080.

49. Cha DJ, Mengel D, Mustapic M, Liu W, Selkoe DJ, Kapogiannis D, Galasko D, Rissman RA, Bennett DA, Walsh DM: miR-212 and miR-132 Are Downregulated in Neurally Derived Plasma Exosomes of Alzheimer's Patients. Frontiers in neuroscience 2019, 13:1208.

50. Dangla-Valls A, Molinuevo JL, Altirriba J, Sanchez-Valle R, Alcolea D, Fortea J, Rami L, Balasa M, Munoz-Garcia C, Ezquerra M, et al: CSF microRNA Profiling in Alzheimer's Disease: a Screening and Validation Study. Molecular neurobiology 2017, 54:6647-6654.

51. Liu S, Li XM, Yuan JB, Li LL, Wang C, Lin XM, Miao X, Shi ZC: MiR-665 inhibits inflammatory response in microglia following spinal cord injury by targeting TREM2. European review for medical and pharmacological sciences 2021, 25:65-70.

52. Heneka MT, Carson MJ, El Khoury J, Landreth GE, Brosseron F, Feinstein DL, Jacobs AH, WyssCoray T, Vitorica J, Ransohoff RM, et al: Neuroinflammation in Alzheimer's disease. The Lancet Neurology 2015, 14:388-405.

53. Lee WS, Lee WH, Bae YC, Suk K: Axon Guidance Molecules Guiding Neuroinflammation. Exp Neurobiol 2019, 28:311-319. 
medRxiv preprint doi: https://doi.org/10.1101/2021.10.29.21265617; this version posted October 30, 2021. The copyright holder for this preprint (which was not certified by peer review) is the author/funder, who has granted medRxiv a license to display the preprint in perpetuity. It is made available under a CC-BY-NC-ND 4.0 International license.

54. Kwart D, Gregg A, Scheckel C, Murphy EA, Paquet D, Duffield M, Fak J, Olsen O, Darnell RB, Tessier-Lavigne M: A Large Panel of Isogenic APP and PSEN1 Mutant Human iPSC Neurons Reveals Shared Endosomal Abnormalities Mediated by APP beta-CTFs, Not Abeta. Neuron 2019, 104:1022. 
Table 1: Demographic Characteristics of the Discovery and Replication Datasets

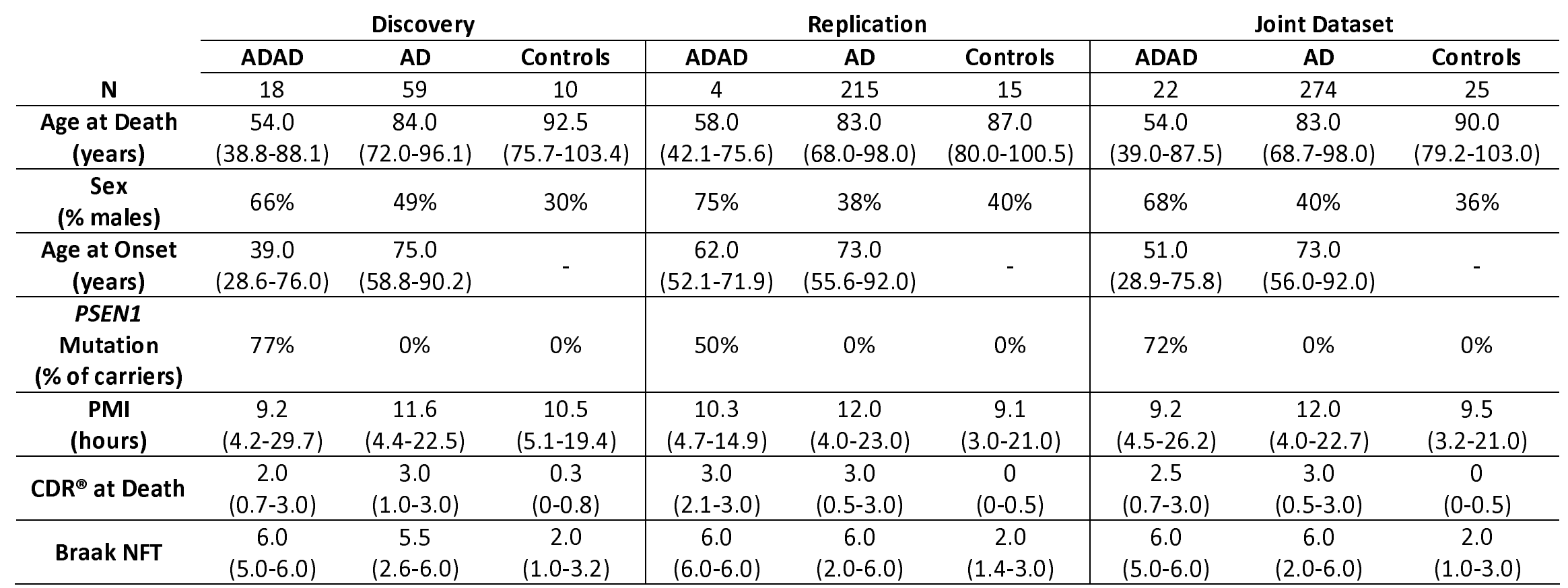

ADAD=Autosomal Dominant Alzheimer Disease; $A D=S$ poradic Alzheimer Disease; PSEN1= Presenilin1; PMI=Post-Mortem Interval; $\mathrm{CDR}^{\oplus}=$ Clincal Dementia Rating; NFT=NeuroFilament Tangles. Age at Death and Age at Onset (AAO) are expressed as median age $(95 \%$ Inter Quartile Interval). 
Table 2: Differential Expression Results

\begin{tabular}{cccccc} 
& & \multicolumn{2}{c}{ Circular PSEN1 } & \multicolumn{2}{c}{ Linear PSEN1 } \\
\cline { 3 - 6 } & & $\log _{2} \mathrm{FC}$ & $\mathrm{P}$ Value & $\log _{2} \mathrm{FC}$ & $\mathrm{P}$ Value \\
\cline { 3 - 6 } ADAD vs Controls & Discovery & 0.811 & $\mathbf{1 . 6 1 \times 1 \mathbf { 0 4 } ^ { - 0 }}$ & 0.192 & 0.107 \\
& Replication & 0.653 & 0.168 & -0.191 & 0.442 \\
& Joint Analysis & 0.786 & $\mathbf{9 . 0 8 \times 1 0 ^ { - 0 5 }}$ & 0.080 & 0.489 \\
\hline \multirow{3}{*}{ ADAD vs AD } & Discovery & 0.523 & $\mathbf{5 . 0 0 \times 1 0 ^ { - 0 3 }}$ & 0.144 & 0.172 \\
& Replication & 0.644 & 0.198 & -0.139 & 0.583 \\
& Joint Analysis & 0.576 & $\mathbf{2 . 0 0 \times 1 0 ^ { - 0 3 }}$ & 0.064 & 0.568 \\
\hline \multirow{2}{*}{ AD vs Controls } & Discovery & 0.289 & 0.208 & 0.101 & 0.434 \\
& Replication & 0.102 & 0.708 & -0.153 & 0.247 \\
& Joint Analysis & 0.142 & 0.441 & -0.061 & 0.540 \\
\hline
\end{tabular}

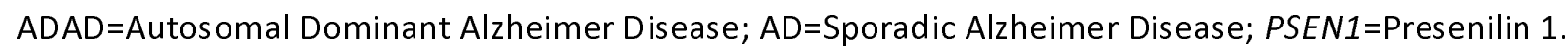


Table 3: Species of circPSEN1 characterization and differences across groups

\begin{tabular}{|c|c|c|c|c|c|c|c|c|c|c|}
\hline \multirow{2}{*}{ circPSEN1 species } & & \multicolumn{3}{|c|}{ Discovery } & \multicolumn{3}{|c|}{ Replication } & \multicolumn{3}{|c|}{ Joint } \\
\hline & & ADADvsCO & ADADvsAD & ADvsCO & ADADvsCO & ADADvsAD & ADvsCO & ADADvsCO & ADADvsAD & ADvsCO \\
\hline \multirow{2}{*}{ hsa_circ_0008521 } & $P$ value & $5.316 \times 10^{-04}$ & 0.004 & 0.278 & 0.379 & 0.491 & 0.449 & $1.494 \times 10^{-04}$ & $6.557 \times 10^{-03}$ & 0.223 \\
\hline & $\log _{2} F C$ & 0.990 & 0.614 & 0.300 & 1.052 & 0.673 & 0.428 & 1.017 & 0.694 & 0.347 \\
\hline \multirow{2}{*}{ hsa_circ_0003848 } & $P$ value & 0.022 & 0.029 & 0.180 & 0.360 & 0.297 & 0.666 & $6.960 \times 10^{-03}$ & 0.041 & 0.773 \\
\hline & $\log _{2} F C$ & 0.701 & 0.436 & 0.295 & 0.972 & 1.148 & -0.266 & 0.769 & 0.536 & 0.082 \\
\hline \multirow{2}{*}{ hsa_circ_0007013 } & $P$ value & 0.796 & 0.795 & 0.386 & 0.811 & 0.750 & 0.780 & 0.843 & 0.704 & 0.499 \\
\hline & $\log _{2} F C$ & -0.338 & -0.174 & 0.766 & 0.884 & 0.614 & 0.292 & 0.206 & 0.262 & 0.443 \\
\hline \multirow{2}{*}{$\begin{array}{c}\text { circPSEN1 } \\
73147795-73165413\end{array}$} & $P$ value & - & - & - & 0.832 & 0.985 & 0.937 & - & - & - \\
\hline & $\log _{2} F C$ & - & - & - & -0.833 & -0.186 & -0.375 & - & - & - \\
\hline \multirow{2}{*}{ hsa_circ_0002564 } & $P$ value & 0.066 & $4.336 \times 10^{-04}$ & 0.706 & 0.636 & 0.656 & 0.769 & 0.059 & 0.012 & 0.585 \\
\hline & $\log _{2} F C$ & 0.723 & 0.859 & 0.126 & 0.325 & 0.264 & 0.092 & 0.640 & 0.600 & 0.128 \\
\hline \multirow{2}{*}{ hsa_circ_0008218 } & $P$ value & - & - & - & 0.995 & 0.687 & 0.912 & - & - & - \\
\hline & $\log _{2} \mathrm{FC}$ & - & - & - & 0.019 & 0.700 & -0.106 & - & - & - \\
\hline \multirow{2}{*}{ hsa_circ_0032509 } & $P$ value & 0.825 & 0.841 & 0.962 & - & - & - & - & - & - \\
\hline & $\log _{2} \mathrm{FC}$ & 0.700 & 0.624 & 0.207 & - & - & - & & & \\
\hline
\end{tabular}

$\mathrm{ADAD}=$ Autosomal Dominant Alzheimer Disease; $\mathrm{AD}=$ Sporadic Alzheimer Disease; $C O=$ Control; PSEN1=Presenilin 1 
Supplementary Table 1. Demographic Characteristics of the Mount Sinai Brain Bank (MSBB) in the different brain regions

\begin{tabular}{|c|c|c|c|c|c|c|c|c|}
\hline & \multicolumn{2}{|c|}{ BM10 } & \multicolumn{2}{|c|}{ BM22 } & \multicolumn{2}{|c|}{ BM36 } & \multicolumn{2}{|c|}{ BM44 } \\
\hline & $A D$ & Controls & $A D$ & Controls & $A D$ & Controls & $A D$ & Controls \\
\hline $\mathbf{N}$ & 143 & 29 & 134 & 26 & 123 & 24 & 132 & 25 \\
\hline $\begin{array}{c}\text { Sex } \\
\text { (\% males) }\end{array}$ & $32 \%$ & $31 \%$ & 0.37 & 0.31 & 0.33 & 0.33 & 0.33 & 0.36 \\
\hline $\begin{array}{c}\text { Age at Onset } \\
\text { (years) }\end{array}$ & $\begin{array}{c}87.0 \\
(71.1-90.0)\end{array}$ & - & $\begin{array}{c}85.0 \\
(71.7-90.0)\end{array}$ & - & $\begin{array}{c}87.0 \\
(71.1-90.0)\end{array}$ & - & $\begin{array}{c}87.0 \\
(72.0-90.0)\end{array}$ & - \\
\hline $\begin{array}{c}\text { PMI } \\
\text { (hours) }\end{array}$ & $\begin{array}{c}5.0 \\
(2.0-15.0) \\
\end{array}$ & $\begin{array}{c}10.0 \\
(4.0-19.6) \\
\end{array}$ & $\begin{array}{c}5.0 \\
(2.0-15.3) \\
\end{array}$ & $\begin{array}{c}8.5 \\
(4.3-19.8) \\
\end{array}$ & $\begin{array}{c}5.0 \\
(2.0-15.0) \\
\end{array}$ & $\begin{array}{c}8.0 \\
(3.2-19.0) \\
\end{array}$ & $\begin{array}{c}5.0 \\
(2.0-15.0) \\
\end{array}$ & $\begin{array}{c}9.0 \\
(4.0-19.8) \\
\end{array}$ \\
\hline
\end{tabular}

$\mathrm{BM}=$ Brodmann; $\mathrm{AD}=$ Sporadic Alzheimer Disease; PMI=Post-Mortem Interval; PMI and Age at Onset is expressed as median age (95\% Inter Quartile Interval). 
Supplementary Table 2. Differential Expression of aggregate cirCPSEN1 and the species identified in the four MSBB brain regions

\begin{tabular}{ccc|cc|cc} 
& \multicolumn{2}{c|}{ Aggregate circPSEN1 } & \multicolumn{2}{c|}{ hsa_circ_0008521 } & \multicolumn{2}{c}{ hsa_circ_0003848 } \\
\cline { 2 - 7 } & log 2 FoldChange P value & log $_{2}$ FoldChange & P value & log $_{2}$ FoldChange & P value \\
\hline BM10 & 0.029 & 0.877 & - & - & -0.292 & 0.397 \\
BM22 & 0.029 & 0.901 & 0.448 & 0.374 & 0.317 & 0.381 \\
BM36 & 0.019 & 0.898 & 0.193 & 0.363 & -0.063 & 0.743 \\
BM44 & 0.215 & 0.143 & 0.434 & 0.061 & 0.548 & 0.194 \\
\hline
\end{tabular}

$\mathrm{BM}=$ Brodmann Area; PSEN1=Presinilin1

Supplementary Table 3. Differential Expression of cirCPSEN1 when adding, Braak NFT, or age at death to the model to test for the independency of linear and circular forms of PSEN1

\begin{tabular}{ccccc}
\multirow{2}{*}{ Model } & \multicolumn{3}{c}{ Sample Size } & \multicolumn{2}{c}{ circPSEN1 DE } \\
\cline { 2 - 5 } & ADAD & AD & log2FoldChange & P value \\
\hline Status+Sex+PMI+TIN+Dataset+BraakNFT & 17 & 212 & -0.005 & 0.918 \\
Status+Sex+PMI+TIN+Dataset+Age at Death & 22 & 274 & -0.011 & 0.051 \\
\hline
\end{tabular}

$\mathrm{DE}=$ Differential Expression, $\mathrm{ADAD}=$ Autosomal Dominant Alzheimer Disease; $\mathrm{AD}=$ Sporadi Alzheimer Disease; PMI=Post-Mortem Interval; TIN=Transcript Integrity Number; NFT=NeuroFiblirary Tangles 
Supplementary Table 4. KEGG pathways identified by DIANA mirPath software to be significantly associated with the miRNA identified by the Circular RNA Interactome to bind circPSEN1.

\begin{tabular}{|c|c|c|c|}
\hline KEGG pathway & $P$ value & KEGG pathway & P value \\
\hline Proteoglycans in cancer & $6.81 \mathrm{E}-09$ & $\begin{array}{l}\text { Adrenergic signaling in } \\
\text { cardiomyocytes }\end{array}$ & 4.47E-03 \\
\hline Axon guidance & $3.39 \mathrm{E}-07$ & Thyroid hormone signaling pathway & 4.47E-03 \\
\hline Hippo signaling pathway & 7.38E-07 & Endometrial cancer & 4.47E-03 \\
\hline $\begin{array}{l}\text { Signaling pathways regulating } \\
\text { pluripotency of stem cells }\end{array}$ & 8.99E-06 & $\begin{array}{l}\text { Transcriptional misregulation in } \\
\text { cancer }\end{array}$ & 4.47E-03 \\
\hline Lysine degradation & $2.48 \mathrm{E}-05$ & Focal adhesion & $5.04 \mathrm{E}-03$ \\
\hline Pathways in cancer & $1.95 \mathrm{E}-04$ & Neurotrophin signaling pathway & $5.26 \mathrm{E}-03$ \\
\hline ErbB signaling pathway & $3.25 \mathrm{E}-04$ & Non-small cell lung cancer & $6.95 \mathrm{E}-03$ \\
\hline Wnt signaling pathway & $5.58 \mathrm{E}-04$ & Oxytocin signaling pathway & $7.00 \mathrm{E}-03$ \\
\hline Dorso-ventral axis formation & $8.02 \mathrm{E}-04$ & AMPK signaling pathway & $7.98 \mathrm{E}-03$ \\
\hline Hepatitis B & $8.09 E-04$ & GABAergic synapse & $7.98 \mathrm{E}-03$ \\
\hline Prostate cancer & $8.40 \mathrm{E}-04$ & Glutamatergic synapse & $7.98 \mathrm{E}-03$ \\
\hline Glioma & $8.40 \mathrm{E}-04$ & Adherens junction & $9.07 \mathrm{E}-03$ \\
\hline TGF-beta signaling pathway & 9.47E-04 & Nicotine addiction & 0.01 \\
\hline MAPK signaling pathway & $9.55 \mathrm{E}-04$ & Dopaminergic synapse & 0.01 \\
\hline PI3K-Akt signaling pathway & $1.98 \mathrm{E}-03$ & cAMP signaling pathway & 0.02 \\
\hline Colorectal cancer & $3.16 \mathrm{E}-03$ & Long-term potentiation & 0.02 \\
\hline Ras signaling pathway & $3.16 \mathrm{E}-03$ & Renal cell carcinoma & 0.02 \\
\hline FoxO signaling pathway & $3.18 \mathrm{E}-03$ & Regulation of actin cytoskeleton & 0.02 \\
\hline Biotin metabolism & 4.47E-03 & Circadian entrainment & 0.03 \\
\hline Pancreatic cancer & 4.47E-03 & Melanoma & 0.03 \\
\hline Chronic myeloid leukemia & 4.47E-03 & Rap1 signaling pathway & 0.03 \\
\hline mTOR signaling pathway & 4.47E-03 & $\begin{array}{l}\text { Retrograde endocannabinoid } \\
\text { signaling }\end{array}$ & 0.04 \\
\hline Amphetamine addiction & 4.47E-03 & & \\
\hline
\end{tabular}


Supplementary Table 5. Common genes within the KEGG pathways identified by DIANA mirPath software and their differential expression in brains of ADAD, AD and, controls for the discovery and the replication datasets

\begin{tabular}{|c|c|c|c|c|c|c|c|c|c|c|c|c|}
\hline \multirow[b]{3}{*}{ Genes } & \multicolumn{6}{|c|}{ Discovery } & \multicolumn{6}{|c|}{ Replication } \\
\hline & \multicolumn{2}{|c|}{ ADADvsCO } & \multicolumn{2}{|c|}{ ADADvsAD } & \multicolumn{2}{|c|}{ ADvsCO } & \multicolumn{2}{|c|}{ ADADvsCO } & \multicolumn{2}{|c|}{ ADADvsAD } & \multicolumn{2}{|c|}{ ADvsCO } \\
\hline & $\log _{2} F C$ & P value & $\log _{2} F C$ & P value & $\log _{2} F C$ & P value & $\log _{2} F C$ & $P$ value & $\log _{2} F C$ & P value & $\log _{2} F C$ & $P$ value \\
\hline AKT2 & -0.0724 & 39E-01 & 0739 & 4.49E-01 & -0.1434 & $37 E-01$ & -0.1171 & $6.34 \mathrm{E}-01$ & -0.2327 & $1.55 \mathrm{E}-01$ & 0.1320 & $1.37 \mathrm{E}-01$ \\
\hline GRB2 & 0.0107 & $8.95 \mathrm{E}-01$ & 0.0010 & $9.84 \mathrm{E}-01$ & -0.0087 & 8.99E-01 & 0394 & 7.29E-01 & 0.1267 & $2.22 \mathrm{E}-01$ & -0.0709 & $1.93 \mathrm{E}-01$ \\
\hline WNT9B & 1527 & $46 \mathrm{E}-01$ & 0.0137 & $9.21 \mathrm{E}-01$ & 0.1663 & $3.55 \mathrm{E}-01$ & 0.5069 & 4.16E-01 & 0.8533 & $3.92 \mathrm{E}-02$ & -0.3010 & $1.53 \mathrm{E}-01$ \\
\hline PRKCB & 0.2241 & 03E-01 & 0.1816 & $2.38 \mathrm{E}-01$ & -0.0038 & $9.84 \mathrm{E}-01$ & -0.2684 & $6.70 \mathrm{E}-01$ & 0.3839 & 2.53E-01 & -0.6003 & $.50 \mathrm{E}-03$ \\
\hline SMAD3 & -0.3122 & $96 \mathrm{E}-02$ & -0.1087 & 1.97E-01 & -0.1160 & $2.78 \mathrm{E}-01$ & 0.0578 & 8.47E-01 & -0.1531 & $3.73 \mathrm{E}-01$ & 0.0037 & $9.70 \mathrm{E}-01$ \\
\hline WNT10B & 0.4645 & $1.89 \mathrm{E}-02$ & 0.5156 & 9.97E-04 & 0.0411 & 8.37E-01 & 0.1361 & 8.74E-01 & 0.4250 & $2.74 \mathrm{E}-01$ & -0.3501 & $1.14 \mathrm{E}-01$ \\
\hline KRAS & 0.2401 & $5.24 \mathrm{E}-02$ & 0.1162 & $2.21 \mathrm{E}-01$ & 0.1 & 3.93E-01 & -0.0538 & 8.36E-01 & 0.2019 & $3.13 \mathrm{E}-01$ & -0 & $1.38 \mathrm{E}-01$ \\
\hline MAP2K1 & -0.0121 & $9.45 \mathrm{E}-01$ & -0.0070 & $9.55 \mathrm{E}-01$ & -0.1054 & 4.94E-01 & -0.2347 & $5.05 \mathrm{E}-01$ & 0.2921 & $2.91 \mathrm{E}-01$ & -0 & $7.78 \mathrm{E}-02$ \\
\hline FZD4 & -0.2342 & $2.60 \mathrm{E}-01$ & -0.2 & 3 & & -01 & & 02 & -0 . & & & \\
\hline PIK3R5 & -1.0713 & $1.01 \mathrm{E}-04$ & -0.5582 & $1.15 \mathrm{E}-02$ & -0.6184 & 2.39E-02 & -0.4223 & $2.62 \mathrm{E}-01$ & -0.6961 & $5.72 \mathrm{E}-02$ & 0.0117 & $9.52 \mathrm{E}-01$ \\
\hline MAPK1 & -0.1731 & $3.46 \mathrm{E}-02$ & -0.1258 & $4.98 \mathrm{E}-02$ & -0. & 4E-01 & 13 & 01 & 52 & 1. & & -01 \\
\hline WNT6 & -0.7467 & $2.25 \mathrm{E}-01$ & -0.6210 & 1.37E-01 & -0.6385 & $2.73 \mathrm{E}-01$ & -0.0388 & $9.61 \mathrm{E}-01$ & -1.2207 & $1.22 \mathrm{E}-01$ & 1.1848 & $5.60 \mathrm{E}-03$ \\
\hline CTNNB1 & -0.1878 & $2.36 \mathrm{E}-03$ & -0.0837 & $1.49 \mathrm{E}-01$ & -0.0865 & 2.43E-01 & 0.2385 & $1.91 \mathrm{E}-01$ & 0.0818 & $3.74 \mathrm{E}-01$ & 0.1692 & $7.80 \mathrm{E}-04$ \\
\hline FZD5 & -0.8505 & $5.23 \mathrm{E}-06$ & -0.2045 & $2.10 \mathrm{E}-01$ & -0.6462 & $2.37 \mathrm{E}-03$ & 10 & 01 & -0.4072 & 01 & 36 & -02 \\
\hline WNT5A & -0.1663 & 3.67E-01 & 0.0032 & $9.78 \mathrm{E}-01$ & -0.1675 & $2.02 \mathrm{E}-01$ & 0.3245 & 3.59E-01 & -0.0031 & $9.89 \mathrm{E}-01$ & 0.3022 & $7.92 \mathrm{E}-03$ \\
\hline SMAD4 & -0.6016 & 7.62E-07 & -0.2880 & 1.17E-03 & -0.2960 & 7.09E-03 & -0.1224 & 4.42E-01 & -0.1173 & 3.66E-01 & -0.0067 & $9.23 \mathrm{E}-01$ \\
\hline WNT2B & -0.0399 & 7.89E-01 & 0.0313 & 7.18E-01 & & $8.65 E-01$ & -0.2666 & 2.93E-01 & & 7.7 & -0 & 8.49E-03 \\
\hline PIK3CG & -0.1939 & 4.56E-01 & 0.0374 & 8.37E-01 & 0.0750 & 7.34E-01 & -0.2287 & 3.92E-01 & -0.2002 & 5.3 & -0.0793 & $6.39 \mathrm{E}-01$ \\
\hline WNT16 & & & & & & & & & & & & \\
\hline PIK3CB & 0.2037 & $1.73 \mathrm{E}-01$ & 0.1259 & 2.29E-01 & 0.0468 & 7.21E-01 & -0.1825 & $3.45 \mathrm{E}-01$ & 0.1385 & $4.86 \mathrm{E}-01$ & -0.2 & $3.27 \mathrm{E}-02$ \\
\hline PRKCA & -0.1297 & 2.74E-01 & -0.2100 & 1.19E-03 & 0.1436 & $3.46 \mathrm{E}-02$ & -0.0207 & 9.37E-01 & -0.0426 & 7.61E-01 & -0.1032 & $1.92 \mathrm{E}-01$ \\
\hline WNT7A & -0.1159 & 6.37E-01 & -0.2102 & $1.87 \mathrm{E}-01$ & -0.0324 & 8.77E-01 & -1.1896 & $1.74 \mathrm{E}-02$ & -0.2755 & $3.60 \mathrm{E}-01$ & -0 & $2.37 \mathrm{E}-08$ \\
\hline GSK3B & 0.1766 & $4.39 \mathrm{E}-02$ & 0.1006 & $2.28 \mathrm{E}-01$ & 0.0 & $\mathrm{E}-01$ & -0.0495 & 7.75E-01 & 0.2256 & $1.69 \mathrm{E}-01$ & -0.1830 & $3.72 \mathrm{E}-02$ \\
\hline AKT3 & 0.2262 & $2.32 \mathrm{E}-02$ & 0.0977 & $2.36 \mathrm{E}-01$ & 0.1178 & 2.91E-01 & 0.0368 & 7.22E-01 & 0.2038 & $1.41 \mathrm{E}-01$ & -0.0873 & $2.32 \mathrm{E}-01$ \\
\hline PIK3CA & 0.0970 & $3.85 \mathrm{E}-01$ & 0.0426 & $5.74 \mathrm{E}-01$ & 0.0530 & $6.02 \mathrm{E}-01$ & -0.1083 & 4.30E-01 & 0.1183 & 3.53E-01 & -0.1586 & $1.88 \mathrm{E}-02$ \\
\hline RAF1 & -0.3583 & $1.22 \mathrm{E}-05$ & -0.1794 & $5.55 \mathrm{E}-04$ & -0.2195 & $2.22 \mathrm{E}-04$ & -0.1442 & 2.62E-01 & -0.2037 & 3.87E-02 & 0.0670 & $1.96 \mathrm{E}-01$ \\
\hline WNT9A & -0.1131 & 8.09E-01 & 0.0392 & $8.88 \mathrm{E}-01$ & 0.0057 & $9.86 \mathrm{E}-01$ & -0.2204 & 7.69E-01 & -0.6735 & $1.61 \mathrm{E}-01$ & 0.1772 & 4.97E-01 \\
\hline FZD8 & -0.5680 & $3.83 \mathrm{E}-02$ & -0.3553 & $7.55 \mathrm{E}-02$ & -0.1821 & 4.65E-01 & -0.7128 & $1.31 \mathrm{E}-01$ & -0.5984 & $9.57 \mathrm{E}-02$ & -0.3548 & $6.93 \mathrm{E}-02$ \\
\hline FZD1 & -0.5506 & $1.36 \mathrm{E}-02$ & -0.2030 & $1.72 \mathrm{E}-01$ & -0.3550 & $4.23 \mathrm{E}-02$ & -0.3247 & 4.83E-01 & -0.5988 & $2.16 \mathrm{E}-02$ & 0.1954 & 1.77E-01 \\
\hline FZD3 & 0.1273 & $3.53 \mathrm{E}-01$ & 0.0992 & 3.57E-01 & 0.0435 & 7.50E-01 & -0.0343 & $9.25 \mathrm{E}-01$ & 0.1636 & 4.44E-01 & -0.1864 & $1.10 \mathrm{E}-01$ \\
\hline FZD6 & 0.1862 & 3.27E-01 & 0.1782 & 1.69E-01 & 0.0854 & $6.02 \mathrm{E}-01$ & 0.0788 & 8.32E-01 & -0.3292 & $1.94 \mathrm{E}-01$ & 0.2061 & $1.22 \mathrm{E}-01$ \\
\hline
\end{tabular}


medRxiv preprint doi: https://doi.org/10.1101/2021.10.29.21265617; this version posted October 30, 2021. The copyright holder for this preprint (which was not certified by peer review) is the author/funder, who has granted medRxiv a license to display the preprint in perpetuity.

It is made available under a CC-BY-NC-ND 4.0 International license.

Figure 1. Comparison of the circular PSEN1 normalized counts in the discovery (Panel A) and replication (Panel $B$ ) datasets and the normalized counts for the linear forms of PSEN1 in the discovery (Panel C) and replication (Panel D) datasets for Controls (grey), AD (Alzheimer disease ocher) and ADAD (autosomal dominant Alzheimer disease - blue).
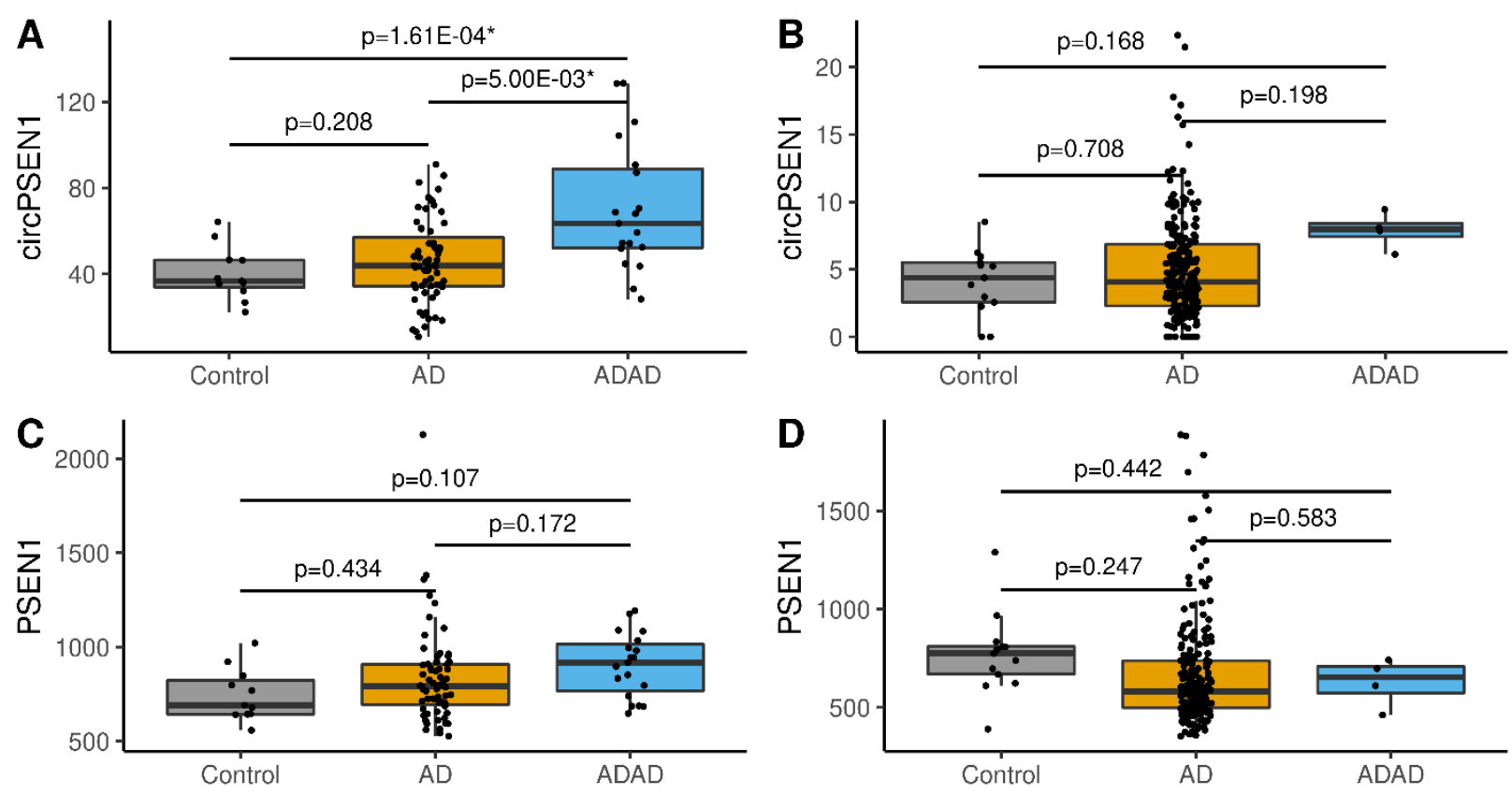
medRxiv preprint doi: https://doi.org/10.1101/2021.10.29.21265617; this version posted October 30, 2021. The copyright holder for this preprint (which was not certified by peer review) is the author/funder, who has granted medRxiv a license to display the preprint in perpetuity.

It is made available under a CC-BY-NC-ND 4.0 International license.

Figure 2. Comparison of the normalized counts of circular PSEN1(Panel A)/linear PSEN1 (Panel B) between controls, AD, and different mutation carriers in the joint dataset - Controls (grey), ADs (Alzheimer disease - ocher), PSEN1 mutation carriers (blue), and APP mutation carriers (green).
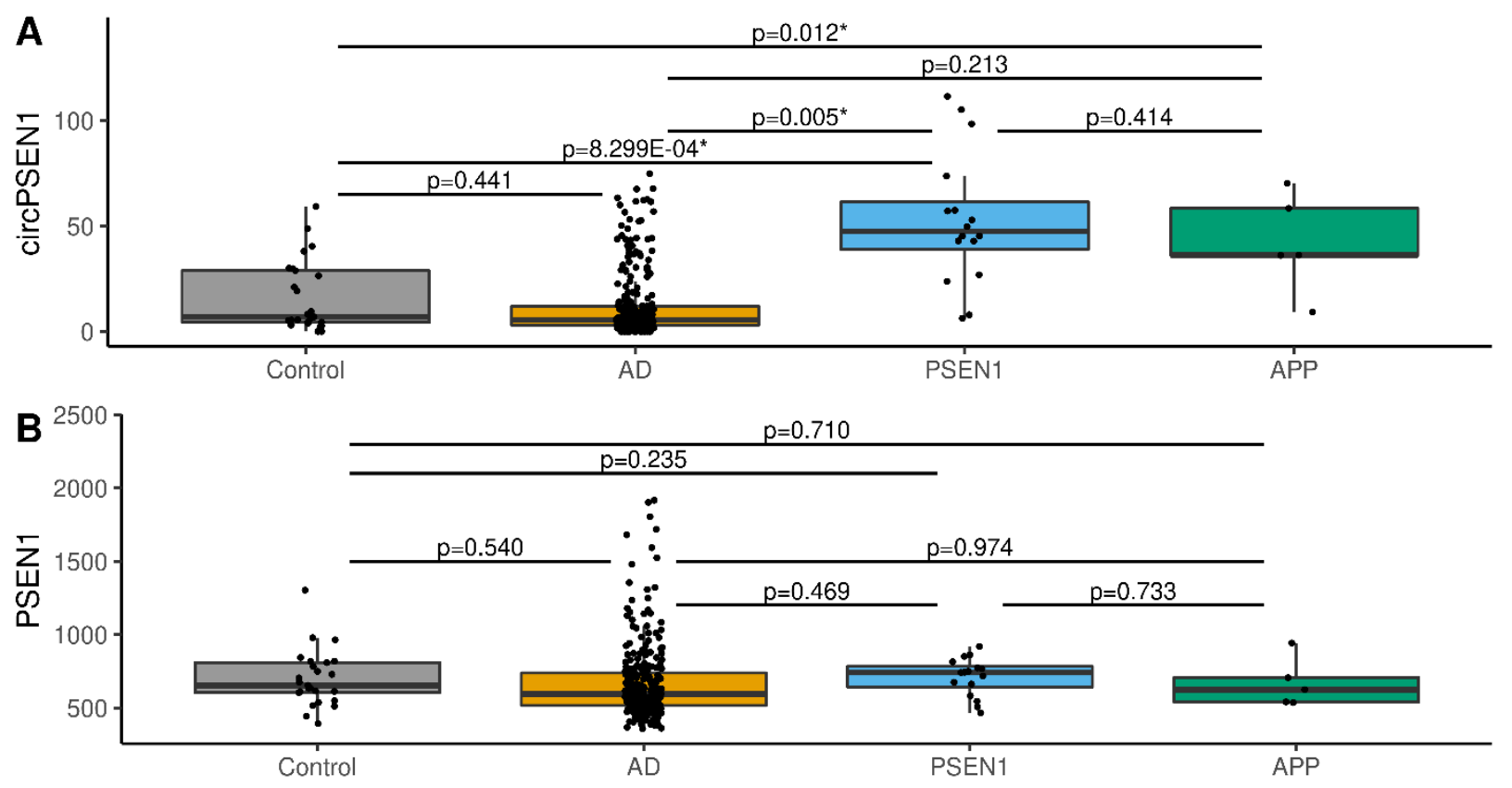
medRxiv preprint doi: https://doi.org/10.1101/2021.10.29.21265617; this version posted October 30, 2021. The copyright holder for this preprint (which was not certified by peer review) is the author/funder, who has granted medRxiv a license to display the preprint in perpetuity. It is made available under a CC-BY-NC-ND 4.0 International license.

Supplementary Figure 1. Circular and linear PSEN1 normalized counts in the Mount Sinai Brain Bank dataset. Panels A to D represent circPSEN1 and panels E to $\mathrm{H}$ linear PSEN1 (BM10, BM22, BM36 and BM44 respectively).
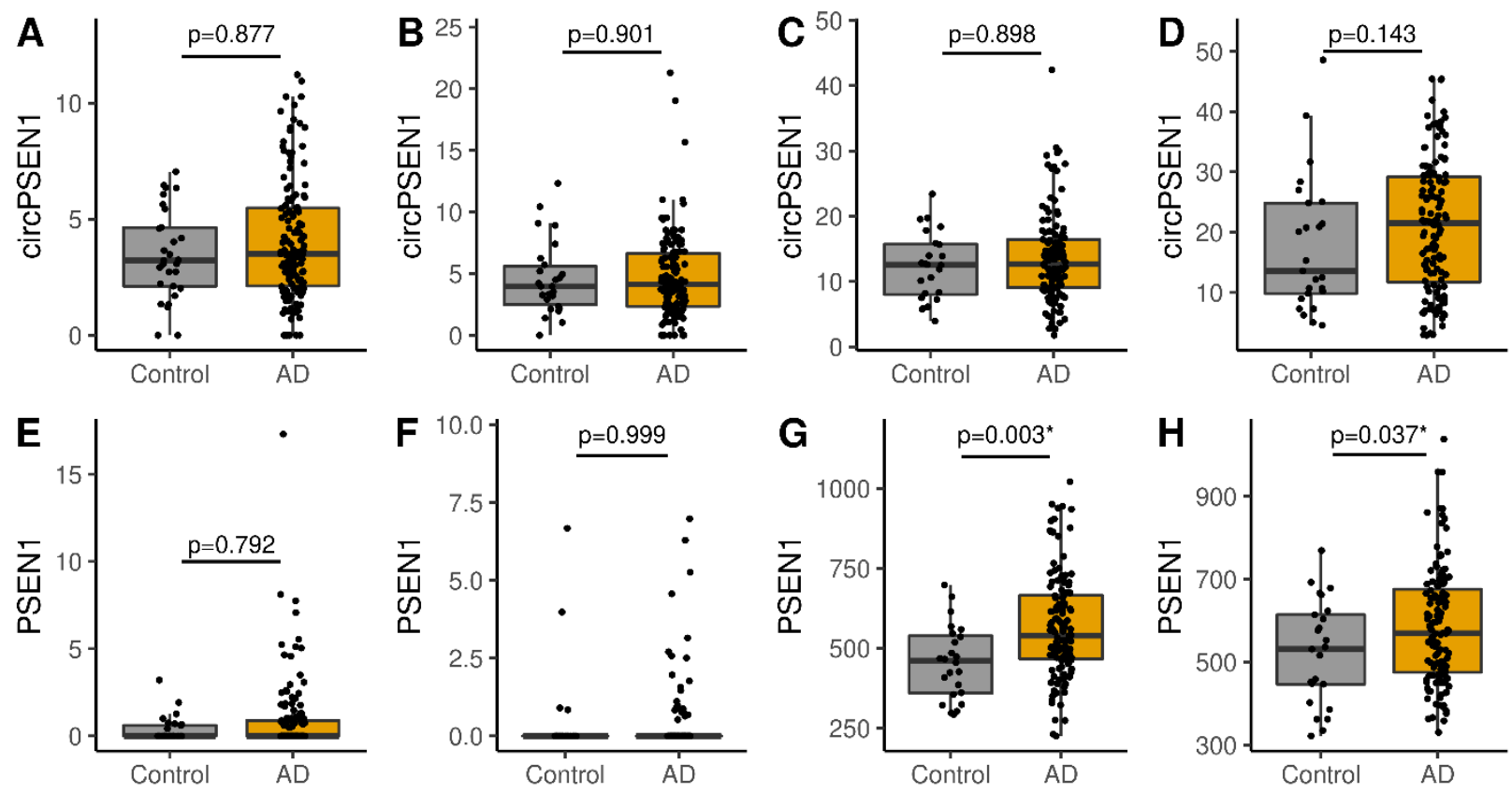
Supplementary Figure 2. Comparison of the circular PSEN1 normalized counts for the three main circPSEN1 species S1 - hsa_circ_0008521 (Panel A in discovery, Panel B in replication), S2hsa_circ_0003848 (Panel C in discovery, Panel D in replication), and S5 - hsa_circ_0002564 (Panel E in discovery, Panel $F$ in replication) for Controls (grey), AD (Alzheimer disease - ocher) and ADAD (autosomal dominant Alzheimer disease - blue)
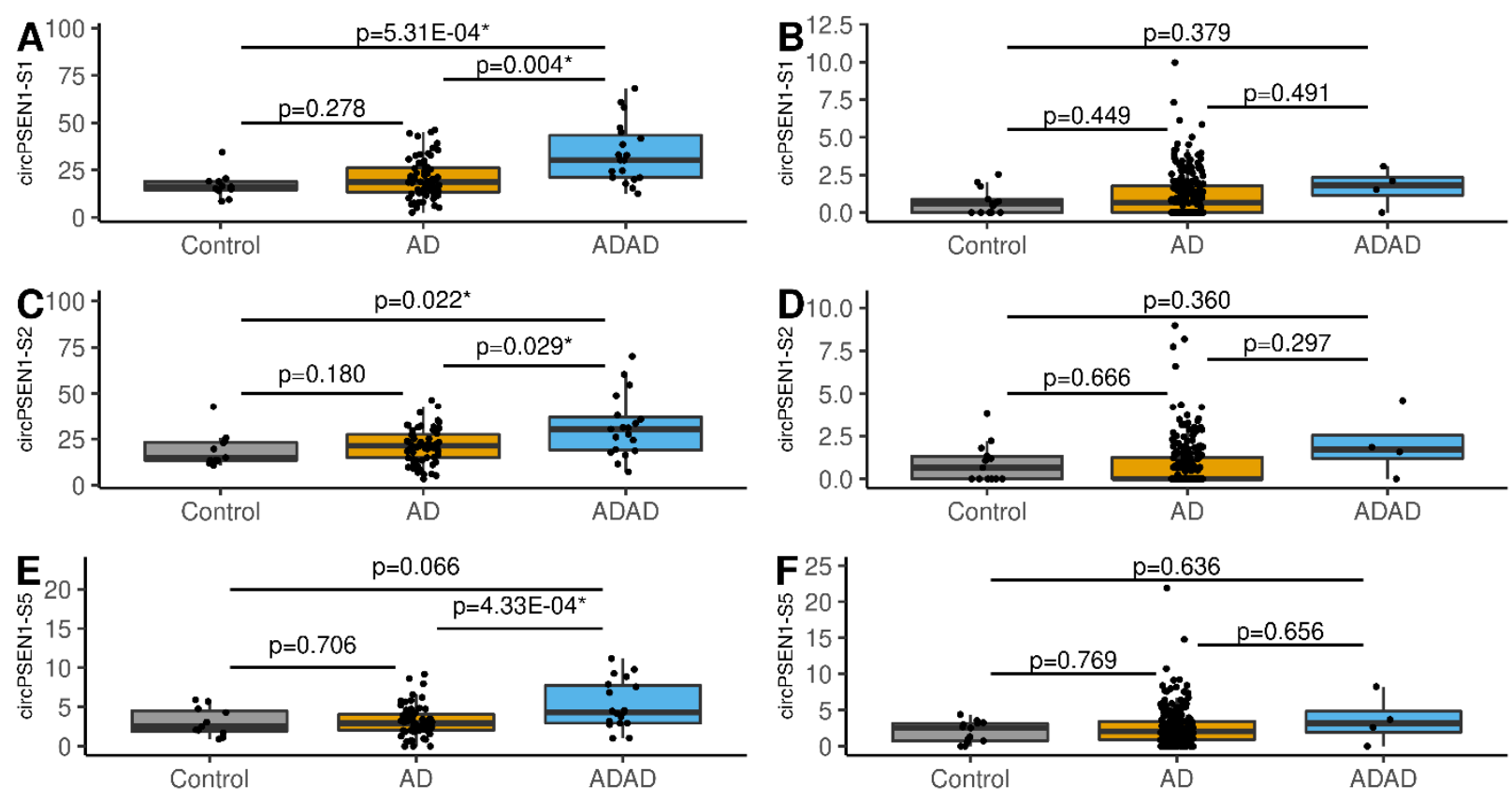
medRxiv preprint doi: https://doi.org/10.1101/2021.10.29.21265617; this version posted October 30, 2021. The copyright holder for this preprint (which was not certified by peer review) is the author/funder, who has granted medRxiv a license to display the preprint in perpetuity. It is made available under a CC-BY-NC-ND 4.0 International license.

Supplementary Figure 3. Correlation of circular PSEN1 normalized counts and linear PSEN1 normalized counts in ADAD (blue), AD (yellow), and controls (gray) for the discovery (Panel A) and replication (Panel B) Datasets
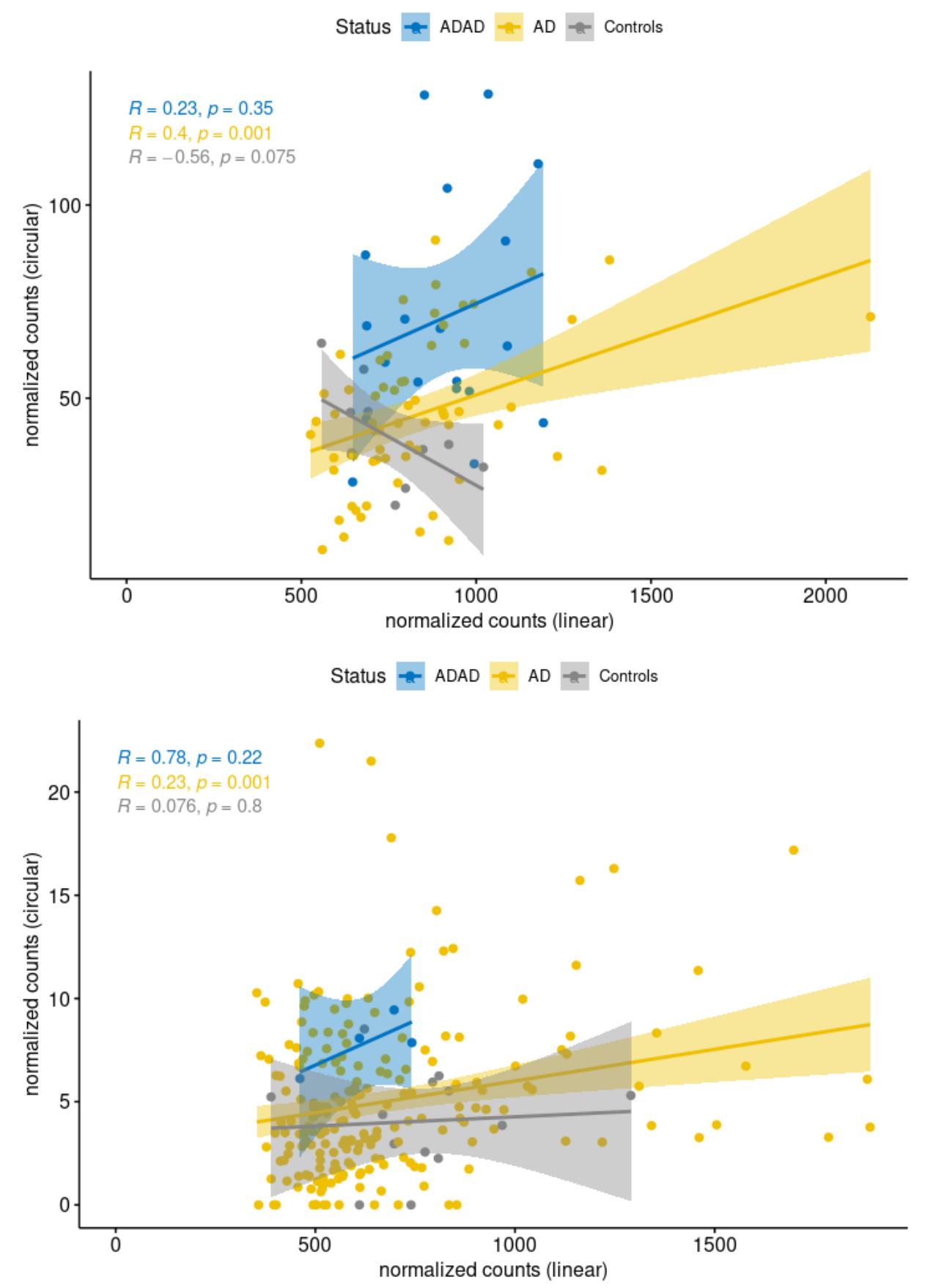
medRxiv preprint doi: https://doi.org/10.1101/2021.10.29.21265617; this version posted October 30, 2021. The copyright holder for this preprint (which was not certified by peer review) is the author/funder, who has granted medRxiv a license to display the preprint in perpetuity.

It is made available under a CC-BY-NC-ND 4.0 International license .

Supplementary Figure 4. ROCs corresponding to the binomial regression models using different circPSEN1 counts (aggregate - red, hsa_circ_0008521 - blue, hsa_circ_0003848 - green) for classifying $A D$ vs Controls (Panel $A$ in discovery and Panel $B$ in replication), ADAD vs AD (Panel $C$ in discovery and Panel $D$ in replication), ADAD vs Controls (Panel $E$ in discovery and Panel $F$ in replication).

A

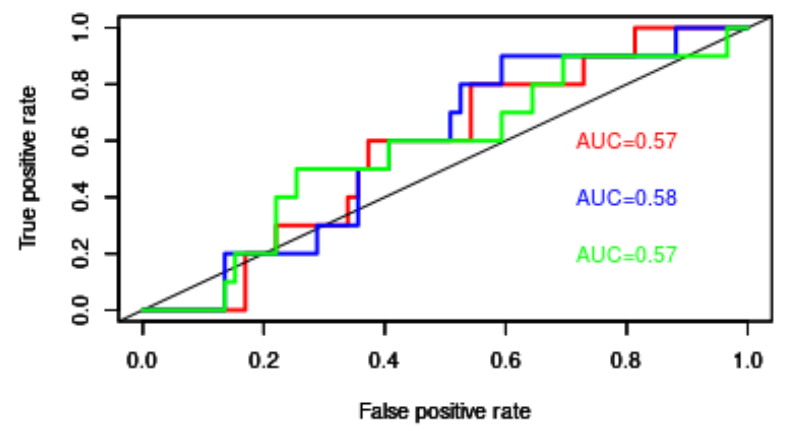

C

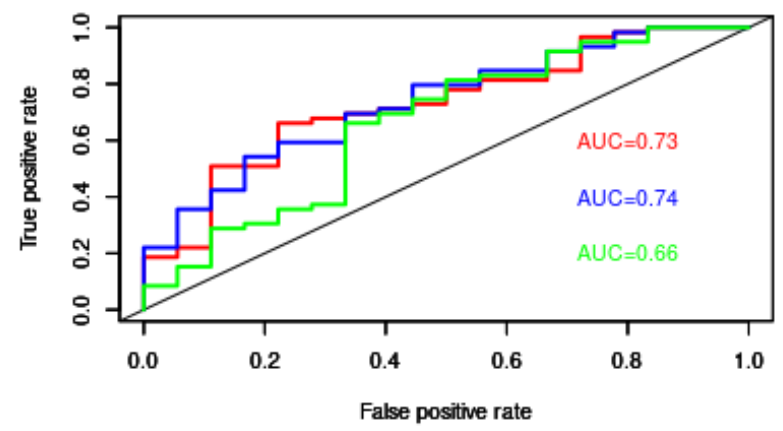

E

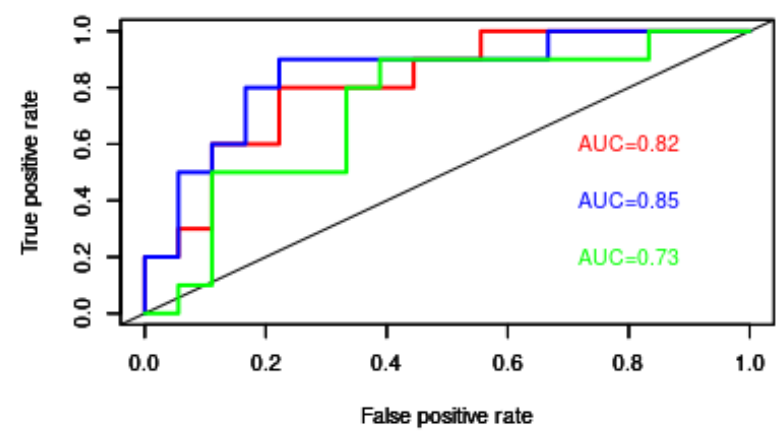

B

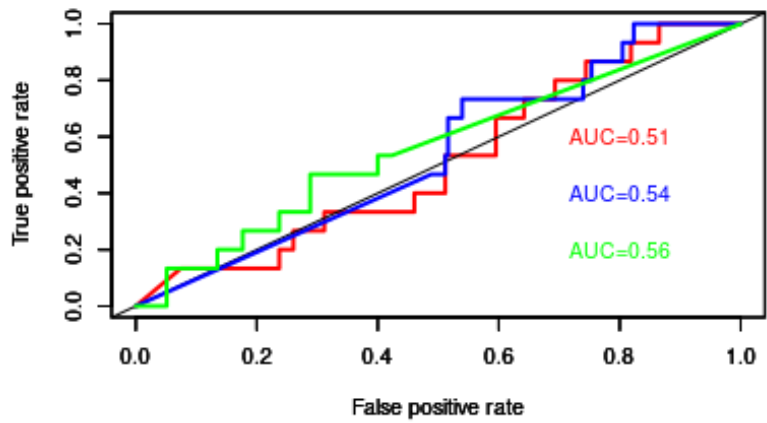

D

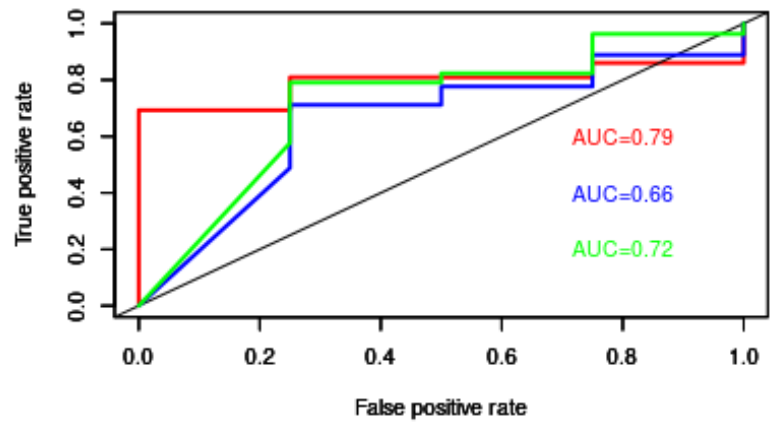

$\mathrm{F}$

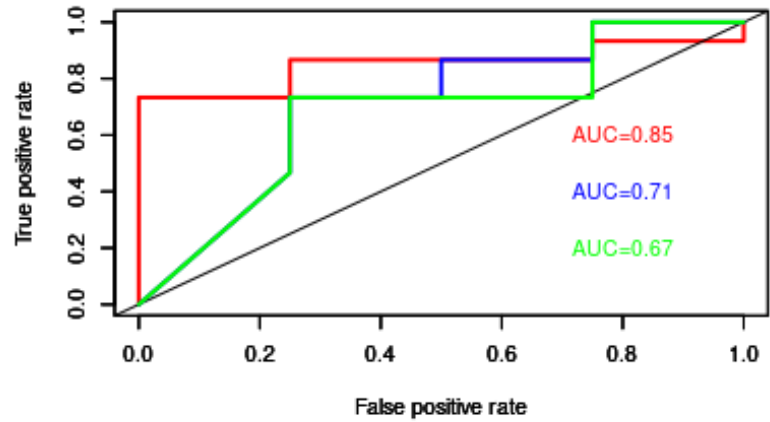

